\title{
Test Plan for FY-94 Digface Characterization Field Experiments
}

\author{
N. E. Josten \\ L. G. Roybal
}

Published August 1994

\section{Idaho National Engineering Laboratory EG\&G Idaho, Inc. Idaho Falls, Idaho 83415}




\section{DISCLAIMER}

This report was prepared as an account of work sponsored by an agency of the United States Government. Neither the United States Government nor any agency thereof, nor any of their employees, make any warranty, express or implied, or assumes any legal liability or responsibility for the accuracy, completeness, or usefulness of any information, apparatus, product, or process disclosed, or represents that its use would not infringe privately owned rights. Reference herein to any specific commercial product, process, or service by trade name, trademark, manufacturer, or otherwise does not necessarily constitute or imply its endorsement, recommendation, or favoring by the United States Government or any agency thereof. The views and opinions of authors expressed herein do not necessarily state or reflect those of the United States Government or any agency thereof. 


\section{DISCLAIMER}

Portions of this document may be illegible in electronic image products. Images are produced from the best available original document. 
Test Plan for FY-94 Digface Characterization Field Experiments

EGG-WTD-11424

Prepared by

As Apter

N. E. Josten, Senior Scientist Applied Geosciences

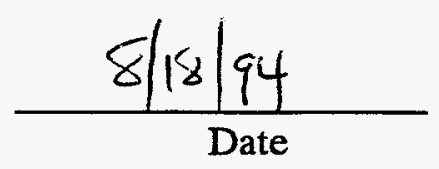

Applied Geosciences

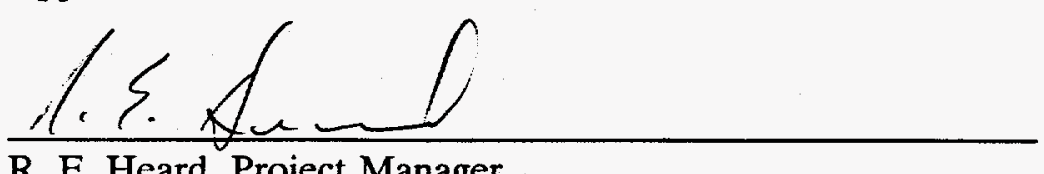

R. E. Heard, Project Manager Buried Waste Integrated Demonstration

Approved by

man astor

K. M. Kostel̄nik, Coordinator

Buried Waste Integrated Demonstration

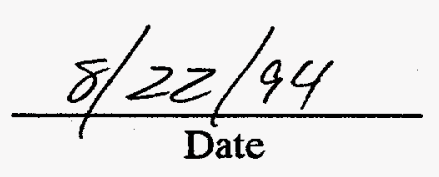




\begin{abstract}
The digface characterization concept has been under development at the Idaho National Engineering Laboratory (INEL) since fiscal year (FY) 1992 through the support of the Buried Waste Integrated Demonstration Program. A digface characterization system conducts continuous subsurface characterization simultaneously with retrieval of hazardous and radioactive waste from buried waste sites. The system deploys multiple sensors at the retrieval operation digface and collects data that provide a basis for detecting, locating, and classifying buried materials and hazardous conditions before they are disturbed by the retrieval equipment. This test plan describes ongoing efforts to test the digface characterization concept at the INEL's Cold Test Pit using a simplified prototype deployment apparatus and off-the-shelf sensors. FY-94 field experiments will explore problems in object detection and classification. Detection and classification of objects are fundamental to three of the four primary functions of digface characterization during overburden removal. This test plan establishes procedures for collecting and validating the digface characterization data sets. Analysis of these data will focus on testing and further developing analysis methods for object detection and classification during overburden removal.
\end{abstract}




\section{SUMMARY}

The Idaho National Engineering Laboratory's (INEL's) Buried Waste Integrated Demonstration (BWID) Program has pursued the development of digface characterization since June 1922. BWID's digface characterization project addresses the need to conduct on-line monitoring during waste retrieval efforts, a need that arises from safety and efficiency considerations during cleanup of a complex waste site. The digface characterization concept was initially demonstrated in fiscal year (FY) 1993 at the INEL's Cold Test Pit. The Cold Test Pit contains simulated waste areas designed to imitate waste configurations found in radioactive/hazardous burial areas throughout the U.S. Department of Energy complex.

During a series of six experiments conducted in FY-93, a combination of geophysical and chemical sensors were used to monitor simulated hazards and buried objects during stepwise excavation of the materials. The prototype sensor suite consisted of a magnetometer, an electromagnetic induction sensor, and a volatile gas detector. The sensor array, sensor deployment equipment, and data handling and analysis electronics form the digface characterization system. The sensor subsystem consists of the instruments and detectors used to interrogate the waste seam. The need to detect and classify a broad assortment of hazard types demands a multisensor approach that addresses chemical, radiological, and physical conditions in the subsurface, The deployment system conveys the sensors to desired measurement points on and above the digface. A high level of development dexterity and precision is required to support the resolution capabilities of the sensors and to adapt to changing conditions at the digface. The data acquisition and analysis subsystem controls sensor function, validates and stores data, and provides an analyst with access to data and data analysis routines for use in evaluating digface conditions.

FY-94 experiments will examine complex waste fields that are representative of real world environments and concentrate on object detection functions within an overburden removal operation. These data will provide a test bed for evaluating and improving the set of prototype data analysis functions previously developed in the FY-93 work. 


\section{CONTENTS}

ABSTRACT $\ldots \ldots \ldots \ldots \ldots \ldots \ldots \ldots \ldots \ldots \ldots \ldots \ldots \ldots \ldots \ldots \ldots \ldots \ldots \ldots$

SUMMARY $\ldots \ldots \ldots \ldots \ldots \ldots \ldots \ldots \ldots \ldots \ldots \ldots \ldots \ldots \ldots \ldots \ldots \ldots$

1. INTRODUCTION $\ldots \ldots \ldots \ldots \ldots \ldots \ldots \ldots \ldots \ldots \ldots \ldots \ldots \ldots \ldots \ldots \ldots$

1.1 Technology Description and Background $\ldots \ldots \ldots \ldots \ldots \ldots \ldots \ldots \ldots \ldots$

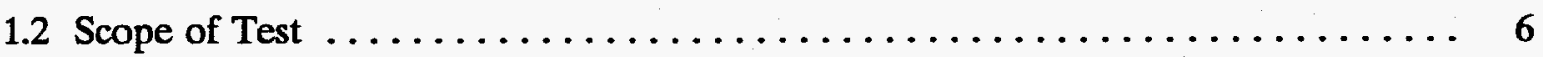

1.3 Test Objectives and Data Quality Objectives $\ldots \ldots \ldots \ldots \ldots \ldots \ldots \ldots$

1.4 Technology Agreement $\ldots \ldots \ldots \ldots \ldots \ldots \ldots \ldots \ldots \ldots \ldots \ldots \ldots \ldots \ldots$

1.5 Customer Need $\ldots \ldots \ldots \ldots \ldots \ldots \ldots \ldots \ldots \ldots \ldots \ldots \ldots \ldots \ldots \ldots$

2. ORGANIZATION AND RESPONSIBILITIES $\ldots \ldots \ldots \ldots \ldots \ldots \ldots \ldots \ldots \ldots$

2.1 Project Personnel $\ldots \ldots \ldots \ldots \ldots \ldots \ldots \ldots \ldots \ldots \ldots \ldots \ldots \ldots \ldots \ldots$

2.2 Testing Responsibilities $\quad \ldots \ldots \ldots \ldots \ldots \ldots \ldots \ldots \ldots \ldots \ldots \ldots \ldots \ldots \ldots$

2.3 Additional Required Support $\ldots \ldots \ldots \ldots \ldots \ldots \ldots \ldots \ldots \ldots \ldots \ldots \ldots \ldots$

2.4 Training Requirements $\ldots \ldots \ldots \ldots \ldots \ldots \ldots \ldots \ldots \ldots \ldots \ldots \ldots \ldots \ldots \ldots$

3. DESCRIPTION OF TEST $\ldots \ldots \ldots \ldots \ldots \ldots \ldots \ldots \ldots \ldots \ldots \ldots \ldots \ldots \ldots \ldots$

3.1 Input, Output, and Test Conditions $\ldots \ldots \ldots \ldots \ldots \ldots \ldots \ldots \ldots \ldots \ldots \ldots$

3.2 Test Overview and Schedule $\ldots \ldots \ldots \ldots \ldots \ldots \ldots \ldots \ldots \ldots \ldots \ldots \ldots \ldots$

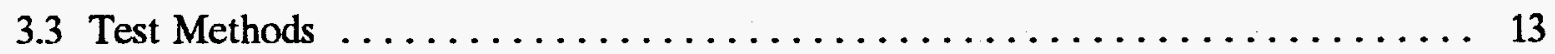

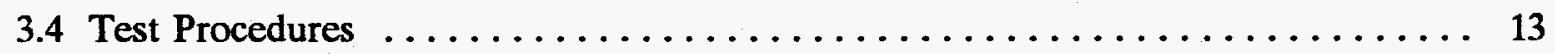

3.5 Diagrams of Test Procedure $\ldots \ldots \ldots \ldots \ldots \ldots \ldots \ldots \ldots \ldots \ldots \ldots \ldots$

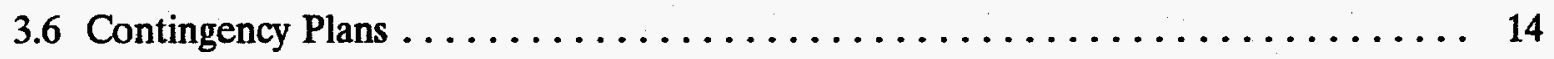

3.7 Performance Objectives $\ldots \ldots \ldots \ldots \ldots \ldots \ldots \ldots \ldots \ldots \ldots \ldots \ldots \ldots \ldots \ldots \ldots$

3.8 Applicability of Testing to Customer Need $\ldots \ldots \ldots \ldots \ldots \ldots \ldots \ldots \ldots$ 
4. SEQUENCE OF ACTIVITIES $\ldots \ldots \ldots \ldots \ldots \ldots \ldots \ldots \ldots \ldots \ldots \ldots \ldots \ldots \ldots \ldots \ldots \ldots$

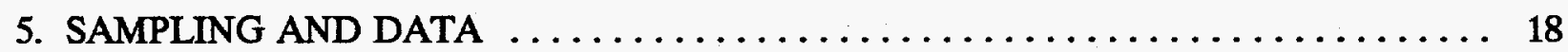

5.1 Applicability to CERCLA Criteria $\ldots \ldots \ldots \ldots \ldots \ldots \ldots \ldots \ldots \ldots \ldots \ldots \ldots \ldots \ldots$

5.2 Data Collection Technique $\ldots \ldots \ldots \ldots \ldots \ldots \ldots \ldots \ldots \ldots \ldots \ldots \ldots$

5.3 Sampling and Data Collection $\ldots \ldots \ldots \ldots \ldots \ldots \ldots \ldots \ldots \ldots \ldots \ldots \ldots \ldots \ldots \ldots$

5.4 Sampling and Analysis Plan $\ldots \ldots \ldots \ldots \ldots \ldots \ldots \ldots \ldots \ldots \ldots \ldots \ldots \ldots \ldots \ldots$

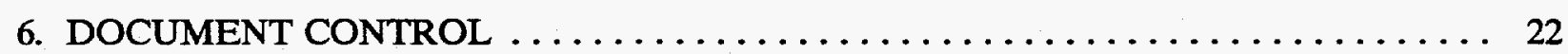

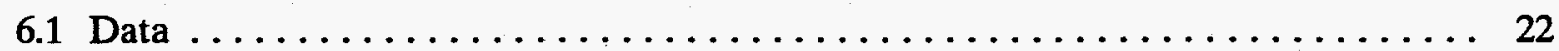

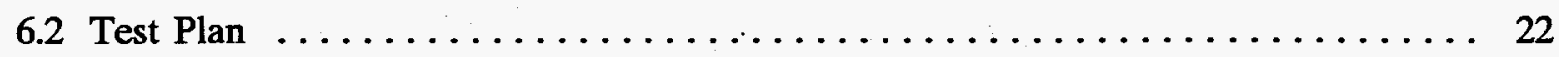

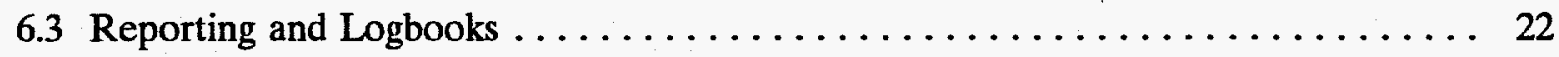

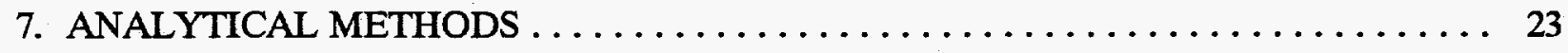

8. DATA REDUCTION, VALIDATION, AND VERIFICATION $\ldots \ldots \ldots \ldots \ldots \ldots 24$

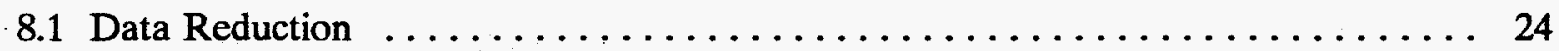

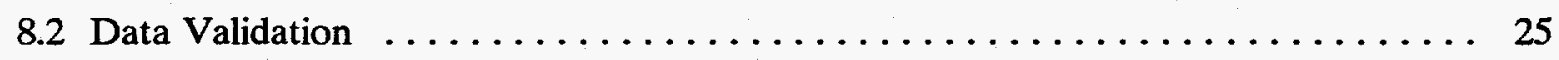

8.3 Responsibility for Data Validation $\ldots \ldots \ldots \ldots \ldots \ldots \ldots \ldots \ldots \ldots \ldots \ldots \ldots \ldots \ldots$

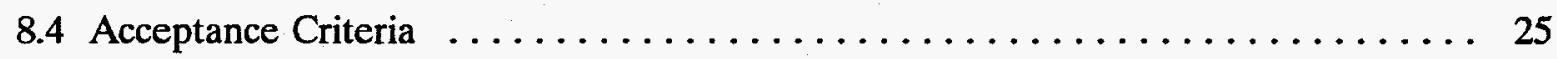

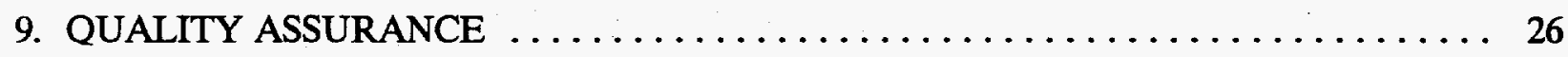

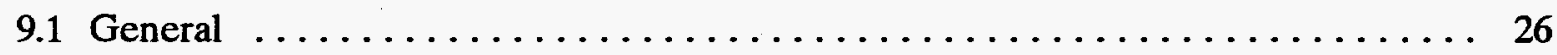

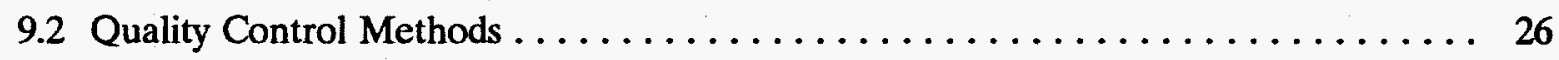

9.3 Specific Quality Control Procedures $\ldots \ldots \ldots \ldots \ldots \ldots \ldots \ldots \ldots \ldots$

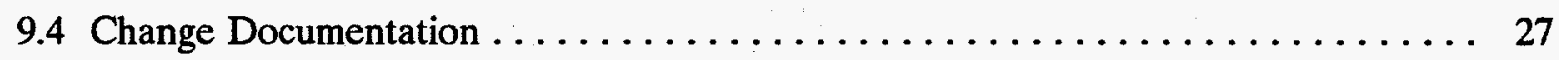

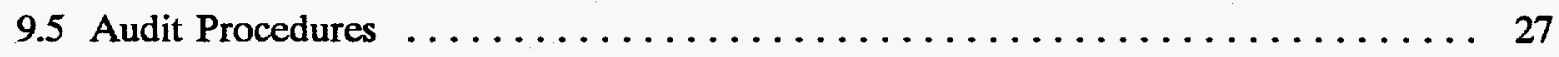

10. EQUIPMENT AND INSTRUMENTS $\ldots \ldots \ldots \ldots \ldots \ldots \ldots \ldots \ldots \ldots \ldots \ldots \ldots$

10.1 Equipment and Suppliers $\ldots \ldots \ldots \ldots \ldots \ldots \ldots \ldots \ldots \ldots \ldots \ldots \ldots \ldots \ldots \ldots \ldots$ 


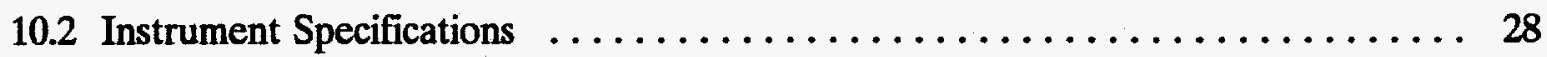

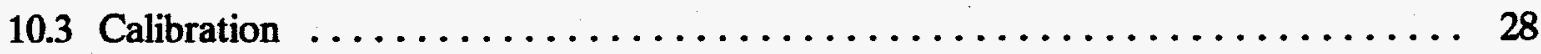

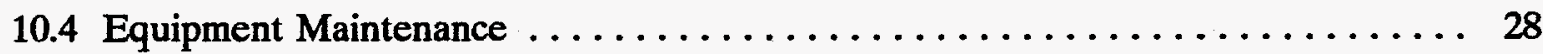

10.5 Equipment Sensitivity to Environmental Conditions $\ldots \ldots \ldots \ldots \ldots \ldots \ldots 28$

11. SUPPLIES, UTILITIES, AND FACILITIES $\ldots \ldots \ldots \ldots \ldots \ldots \ldots \ldots \ldots \ldots$

12. HEALTH AND SAFETY $\ldots \ldots \ldots \ldots \ldots \ldots \ldots \ldots \ldots \ldots \ldots \ldots \ldots \ldots \ldots \ldots \ldots \ldots \ldots$

13. RESIDUALS MANAGEMENT $\ldots \ldots \ldots \ldots \ldots \ldots \ldots \ldots \ldots \ldots \ldots \ldots \ldots \ldots \ldots$

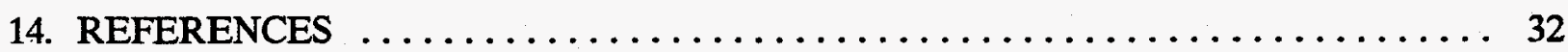

Appendix A-General Field Procedures for FY-94 Digface Tests $\ldots \ldots \ldots \ldots \ldots \ldots \ldots$ A-1

Appendix B-Sensor Technical Specification $\ldots \ldots \ldots \ldots \ldots \ldots \ldots \ldots \ldots \ldots \ldots \ldots \ldots \ldots \ldots$ B-1

\section{FIGURES}

1. Three major digface characterization subsystems within the context of a complex

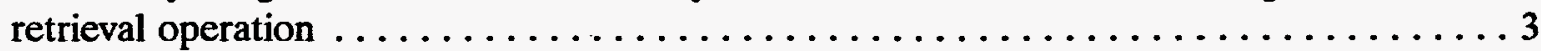

2. Schematic illustration showing function of digface characterization system during overburden removal $\ldots \ldots \ldots \ldots \ldots \ldots \ldots \ldots \ldots \ldots \ldots \ldots \ldots \ldots \ldots$

3. Schematic illustration showing function of digface characterization during waste

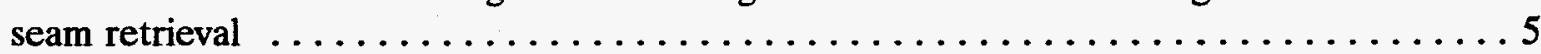

4. INEL's Cold Test Pit showing area of the proposed excavation for the digface

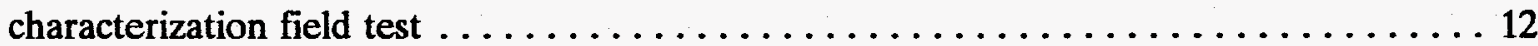

5. Sequence of trolley motions required to survey a three volume $\ldots \ldots \ldots \ldots \ldots \ldots$

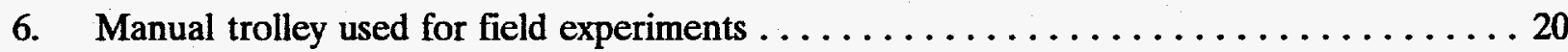




\section{TABLES}

1. Digface characterization project personnel $\ldots \ldots \ldots \ldots \ldots \ldots \ldots \ldots \ldots \ldots \ldots$

2. Applicability of digface characterization to CERCLA criteria $\ldots \ldots \ldots \ldots \ldots$

3. Operating parameters and conversion factors for the trolley deployed digface

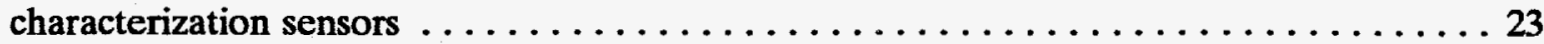




\section{Test Plan for FY-94 Digface Characterization Field Experiments}

\section{INTRODUCTION}

Digface characterization addresses the fundamental need to conduct on-line monitoring during waste retrieval efforts, a need that arises from safety and efficiency considerations during the cleanup of a complex waste site. Waste retrieval involves initial, uncontrolled contact with unknown and potentially dangerous materials and constitutes one of the biggest safety risks during a remedial program. Waste retrieval also initiates a complex sequence of events that includes assaying, sorting, treating, and disposing of the retrieved waste. These downstream activities strongly influence the speed, cost, and effectiveness of the remediation process. Information concerning conditions at the active digface can be used by operators as a basis for adjusting retrieval activities to reduce safety risks and to promote an efficient transition between retrieval and downstream operations. Most importantly, workers are given advance warning of upcoming dangerous conditions. In addition, detailed knowledge of digface conditions provides a basis for selecting tools and methods that avoid contamination spread and work stoppages.

The Digface Characterization Project has pursued development of this technology since June 1992 through the support of the Buried Waste Integrated Demonstration (BWID) Program. The digface characterization concept was initially demonstrated in FY-93 at the Idaho National Engineering Laboratory's (INEL's) Cold Test Pit. The Cold Test Pit contains simulated waste areas designed to imitate waste configurations found in radioactive/hazardous burial areas throughout the U.S. Department of Energy (DOE) complex. During a series of six experiments, a combination of geophysical and chemical sensors were used to monitor simulated hazards and buried objects during stepwise excavation of the materials. The prototype sensor suite consisted of a magnetometer, an electromagnetic induction sensor, and a volatile gas detector.

In FY-94, new experiments will examine complex waste fields that are more representative of real world environments. The new data will provide a vehicle for demonstrating object detection capabilities relevant to the newly refined role of digface characterization. These data will also serve as a test bed for evaluating and improving a set of prototype data analysis functions developed based on the FY-93 work. This test plan describes the objectives and activities of the experiments that will transpire starting in July 1994.

\subsection{Technology Description and Background}

A sensor array, sensor deployment equipment, and data handling and analysis electronics combine to form the digface characterization system. The sensor subsystem consists of the instruments and detectors used to interrogate the waste seam. The need to detect and classify a broad assortment of hazard types demands a multisensor approach that addresses chemical, radiological, and physical conditions in the subsurface. The deployment subsystem conveys the sensors to desired measurement points on and above the digface. A fairly high level of deployment dexterity and precision is required to support the resolution capabilities of the sensors and to adapt to changing conditions at the digface. The data acquisition and analysis subsystem controls sensor 
function, validates and stores data, and provides an analyst with access to data and data analysis routines for use in evaluating the digface conditions. The information developed by the analyst is used by other remediation operators to guide future actions. Figure 1 shows a schematic illustration of the digface characterization subsystems within the context of a waste retrieval operation.

During the overburden removal phase of site remediation, digface characterization will function in a horizontal scanning mode similar to operations conducted during the FY-93 field experiments. The system performs four basic functions during overburden removal as shown in Figure 2 . The first three functions listed in Figure 2 fall under the category of object detection and classification.

Geophysical sensors scan the digface monotonously as the overburden cap is stripped away. The geophysical data generate a progressively clearer view of the waste configuration, its compartments and boundaries. Objects and groups of objects are classified into finer and finer subgroups and object position estimates are generated and updated constantly to keep the excavation equipment clear of solid waste materials. The fourth function listed in Figure 2 is hazard detection, which the digface characterization system performs during all operations. The soil surface is monitored continuously for chemical and radioactive hot spots. In summary, the overburden removal phase allows the characterization system to develop the best possible top view image of the waste configuration before starting the more hazardous waste retrieval phase.

During waste seam excavation phase of site remediation, the digface characterization system will function in a near vertical scanning mode. The three primary functions of the system during waste seam excavation are illustrated in Figure 3. The most common and important function will be routine monitoring for radioactive and chemical hazards that appear as waste is removed and new material is exposed. Detailed investigation of material in situ may occasionally be performed when suspicious or dangerous objects are exposed. Systematic object detection techniques of the type featured during overburden removal will most likely play a minor role (e.g., when it is desired to locate a particular object to avoid collision with the excavation equipment).

The FY-94 field experiments will concentrate on object detection functions within an overburden removal operation. The equipment, sensors, and methodologies for this problem already exist in prototype form. 


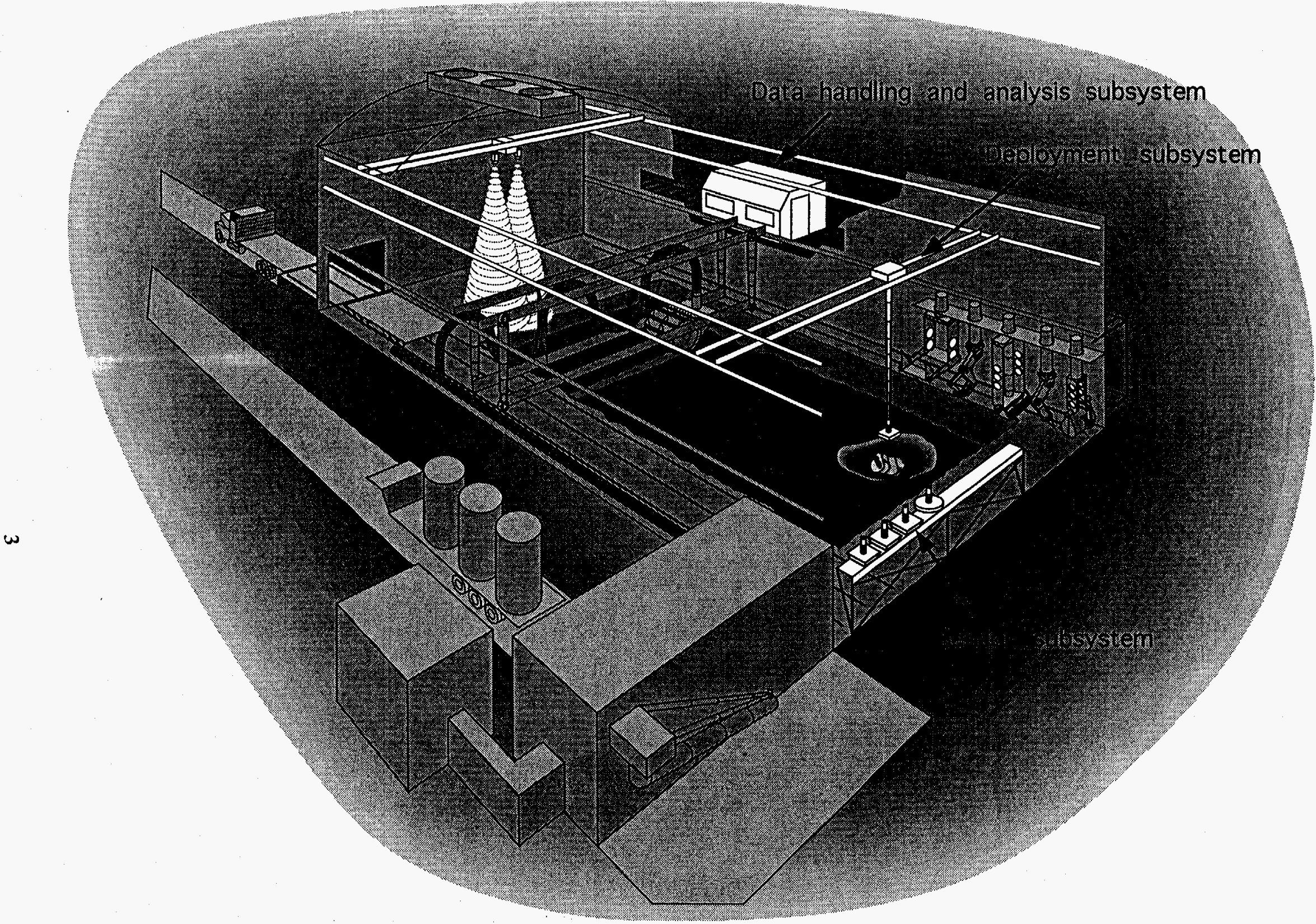

Figure 1. Three major digface characterization subsystems within the context of a complex retrieval operation. 

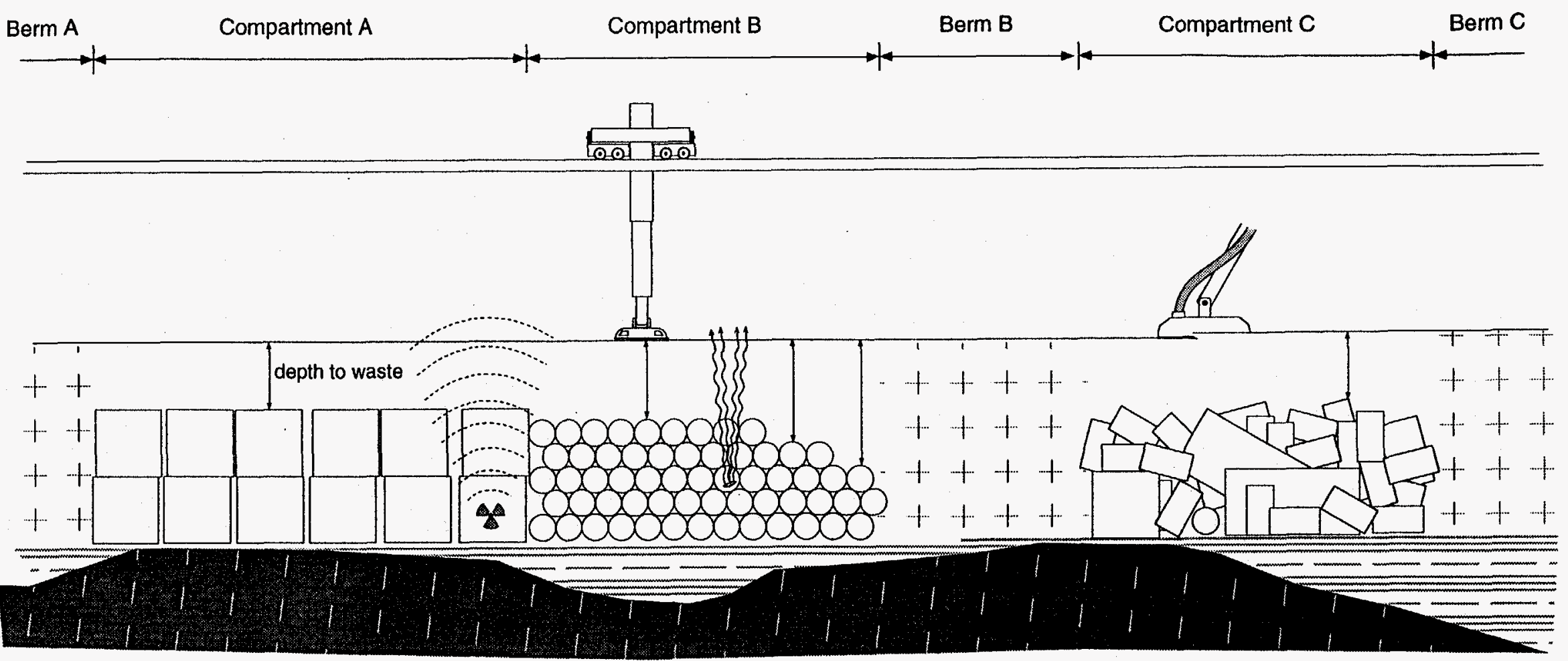

\section{Features of overburden removal}

1. Systematic, controlled excavation of soil only

2. Avoid contamination of clean soil

3. Repetitive, precision, planar, multi-level scans performed by dig-face characterization system under ideal conditions

\section{Dig-face Characterization functions during overburden removal}

1. Provide estimates of depth to waste - basis for achieving maximum removal of clean overburden

2. Construct map of waste "compartment" boundaries and berms in plan view useful for planning barrier locations or stopping points

3. Establish general characteristics of each waste compartment - link to historical records

4. Locate major radioactive or volatile contaminant hot spots and unusual waste objects - used to plan retrieval strategy

Figure 2. Schematic illustration showing function of digface characterization system during overburden removal. 


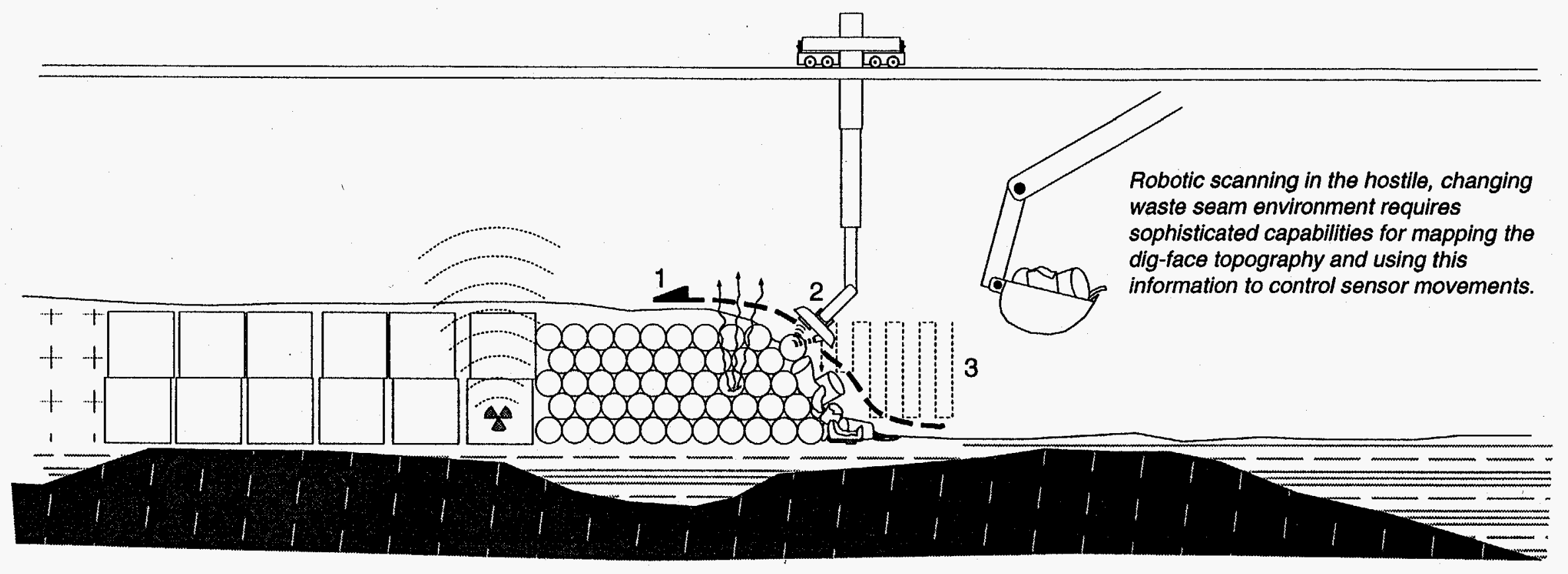

\section{Features of waste seam excavation}

1. Heavy construction style digging in hostile, uncontrolled environment of the waste seam

2. Assume all recovered material will require assay, but only a portion will require expensive processing or treatment

3. Waste seam environment changes constantly

\section{Dig-face characterization functions during waste seam excavation}

1. Routine scanning to monitor radioactive and volatile contaminant hot spots

2. In-depth in situ assay of exposed suspicious containers

3. Occasional systematic geophysical surveys to locate important objects such as reactor cores, vehicles etc.

Figure 3. Schematic illustration showing function of digface characterization during waste seam retrieval. 


\subsection{Scope of Test}

The Digface Characterization Program consists of multiple tasks supporting different elements of the complete system including sensor development, remote deployment, data analysis methods, and the FY-94 field experiments. Specialized sensors for volatile gas detection and radiation field mapping are being developed to perform standard hazard detection functions. A full-scale deployment and data acquisition system is being assembled for use in planned remotely operated waste retrieval. Automated data analysis techniques are being developed to improve the quality and speed of data interpretation following each increment of data collection. These efforts are being pursued separately in FY-94 and will be integrated into a singular system for demonstration in FY-95.

This test plan describes only the FY-94 field experiment activities. These activities involve operation of the fully functional prototype digface characterization system under field conditions. The experiments provide critical experience with digface operations at a small scale. Data collected in the field experiments form the basis for developing and testing new methods of data analysis. Observations concerning equipment, operations, and environmental factors during the field tests are used to guide development of the more sophisticated and expensive full-scale system.

The field experiments will focus on improving object detection and classification capabilities for complex burial scenarios representative of real world waste sites. The object detection capabilities of a digface characterization system in overburden removal mode will be demonstrated by operating the prototype system along a trench excavated across the southernmost four cells of the Cold Test Pit. This section of the Cold Test Pit contains areas of large objects, stacked drums, random drums, stacked boxes, and random boxes.

The equipment developed in FY-93 has been modified to improve performance. The digface trolley has been updated to limit the effects of elastic stress and thermal expansion of the fiberglass and plastic members, and the data acquisition system has been updated to allow bi-directional data collection. Additionally, modifications to the frequency domain electromagnetic induction sensor (Geonics EM-38) have been made to allow the simultaneous collection of quadrature and inphase data thereby doubling data collection rates. Two additional geophysical sensor packages have been added to the sensor subsystem. The Geonics EM-61, a time domain electromagnetic induction instrument, will provide a complementary data set that augments both the magnetic and frequency domain induction measurements. Ground radar will also be evaluated on a limited basis, particularly in areas where nonmetallic waste is suspected.

\subsection{Test Objectives and Data Quality Objectives}

The FY-94 field experiments have a single objective: collect new geophysical data over complex waste areas to extend FY-93 experience with object detection and classification under overburden removal conditions.

The section of the Cold Test Pit proposed for the FY-94 tests includes portions of four waste cells containing thick layers of simulated waste in the form of drums, boxes, and large objects. Two of the cells contain orderly arrangements of waste containers, one cell contains a mixture of randomly dumped containers, and one cell contains various large objects and object groups. This setting 
provides an excellent testbed to evaluate the three object detection functions required during overburden removal. These functions are listed below with references to published BWID test goals. ${ }^{1}$

1. Estimating depth to waste-Differences in the original cell configurations, compaction, and settling have created differences in the amount of overburden covering each cell. This provides a realistic test for depth estimation scenarios. Nonmetallic objects in Cells 1,2 , and 4 provide specific targets for ground radar, which may become important in the depth estimation problem (BWID Test Goal 4.1.3).

2. Waste compartment mapping-Existence of discrete cells and berms provides a test for compartment boundary mapping (BWID Test Goal 4.1.1).

3. Waste classification-Four test cells contain distinctly different types and arrangements of objects. This scenario provides a means to demonstrate capabilities for distinguishing basic differences between the cells, classifying orderly versus random cells, classifying differences in the size, shape, and number of elements comprising the orderly cells, and distinguishing between discrete large objects versus collections of small objects (BWID Test Goal 4.4.1).

Data Quality Objectives for the field experiments establish minimum requirements for the geophysical data to achieve the test objectives. The Data Quality Objectives are as follows:

1. Magnetometer, EM-38, and EM-61 data shall be acquired at data spacings not to exceed $1 / 2$ the depth from the sensor to the top of the shallowest object underlying the trolley survey area.

2. The trolley shall track and report the position of the sensors to within \pm 1 in. for all sensor measurements.

3. At least $60 \%$ of the full trench length shall be surveyed using at least two of the geophysical sensors at a minimum of four elevation levels each. At least three parallel lines of ground radar data shall be acquired along the trench bottom with a minimum line length of $40 \mathrm{ft}$.

4. All data shall adhere to the acceptance criteria listed in Section 8.4.

\subsection{Technology Agreement}

Development of the digface characterization system is supported by the BWID Program under Technical Task Plan \#ID1-3-20-03.

\subsection{Customer Need}

The digface characterization concept and FY-94 field tests address basic needs for site characterization before and during waste retrieval at hazardous sites. Many of the specific needs are clearly documented in Hyde and Morrison. ${ }^{1}$ In addition, the digface characterization system provides 
a basis for investigating unforeseen problems that may develop during an actual site clean-up, which could impact the safety and efficiency of the remedial operation. 


\section{ORGANIZATION AND RESPONSIBILITIES}

The digface characterization field testing will rely primarily on personnel from the Applied Geosciences Unit of EG\&G Idaho, Inc. at the INEL although electrical and mechanical engineering support may be required should equipment problems be encountered. Dr. B.K. Sternberg from the University of Arizona will assist with tests involving the ground radar system. Key project personnel are listed in Table 1 according to tasks and responsibilities. In addition to the listed BWID project manager, the BWID organization includes managers with responsibilities for coordinating other programs using the Cold Test Pit during the summer of 1994.

\subsection{Project Personnel}

Table 1. Digface characterization project personnel.

R.A. Callow

N.E. Josten

L.G. Roybal

G.S. Carpenter

M.V. Carpenter

M. Ward

R.G. Berg

B. K. Sternberg
BWID Project Manager. Mr. Callow has ultimate responsibility in decision making during the field tests including approval for modifying, delaying, or canceling portions of the testing due to safety, schedule, or other unforeseen concerns.

Principal Investigator. Mr. Josten is responsible for the overall technical management of the project. He will also direct the field testing and the data analysis activities during and after the field tests.

Lead Engineer. Mr. Roybal is responsible for coordinating and directing the technical activities required to prepare for the field tests. This includes modifications made to the trolley and data acquisition system.

Geophysicist. Mr. Carpenter is responsible for the data base design and implementation. Mr. Carpenter will also assist in data analysis and interpretation.

Geophysics Technician. Mr. Carpenter is responsible for coordinating the field activities including obtaining facility, equipment, and labor support.

Mechanical Engineer. Mr. Ward is responsible for the mechanical modifications made to the digface trolley system designed and built originally in FY-93.

Data Acquisition Specialist. Mr. Berg is responsible for the hardware and software implementation used in the data acquisition system.

Ground Radar Specialist. Dr. Sternberg is responsible for technical aspects of the ground radar testing. 


\subsection{Testing Responsibilities}

The BWID project manager will have ultimate responsibility in decision making during planning and testing. Should a safety concern arise, the project manager and a safety engineer will decide how to solve the problem and whether to terminate testing. If the testing takes longer than planned, the project manager has the authority to delay or defer testing in order to balance overall project objectives and milestones.

The principal investigator will direct all technical activities including preparation of the prototype system, checkout of the system prior to field deployment, and oversight of the field program and data analysis. The principal investigator will ensure that procedures are followed and that collected data are verified and adequate to meet the objectives for the performance tests. The principal investigator has authority to modify field procedures as necessary to handle unforeseen circumstances, as long as these changes are consistent with the project objectives and properly documented as described in Section 6.2 of this test plan.

\subsection{Additional Required Support}

Additional support will be required to place survey control near the experiment site, excavate the experiment site to a desired depth, and provide a $120 \mathrm{Vac}$ power source nearby to the site for the data acquisition system. This support will be provided by EG\&G Idaho surveyors, equipment operators based at the Radioactive Waste Management Complex (RWMC) and by BWID, respectively.

Monitoring and surveillance will include routine visits from BWID Quality and Safety Oversight personnel.

\subsection{Training Requirements}

No specific training or qualifications are required for personnel involved directly with the digface characterization field tests. Personnel will work under direct supervision of the principal investigator or lead engineer. Unescorted visitors to the test site will require blue card training in accordance with EG\&G Idaho's standard policy. 


\section{DESCRIPTION OF TEST}

The FY-94 digface characterization tests will be conducted over the southern portion of the Cold Test Pit approximately as shown in Figure 4. The site will be excavated to the top of waste (or to a maximum depth of $5 \mathrm{ft}$ if no waste is encountered) along a narrow trench that the trolley system will span. The trolley will be rolled and positioned over the desired test area, and data will be collected on successive horizontal planes within the air space of the pit. Once data collection is completed over a given test section, the trolley will be positioned over the next section by rolling it forward.

One or two areas will be selected for evaluation of ground radar. The radar tests will be conducted on successive horizontal planes as with the other instruments, but will require removal of thin layers of soil prior to each new survey. These soil layers will be removed by hand digging. In this way, the effect of the overburden depth on radar will be investigated. Past experience with radar at the Cold Test Pit has shown that overburden depth is an important performance factor.

The PC-based acquisition system assembled for the FY-93 tests (and slightly modified for FY-94) will $\log$ and scale raw data, storing the results immediately in a data base system. One of the data base functions is a downloading procedure enabling the structured data to be transported easily to other computers. Analysis, both conventional and using newly developed methods, will take place in the Idaho Falls offices.

System performance will be assessed through comparison of estimates of site conditions against actual conditions at the Cold Test Pit. It may be necessary to locally hand excavate the test pit to expose and document the location of simulated waste.

NOTE: Digface characterization is somewhat unique among the technologies being developed and tested by BWID in that there is no existing precursor in the government or private sectors. Thus, the system has been assembled from very basic components. The development work conducted in FY-93 and the work planned for FY-94 are aimed at defining basic capabilities of the system with minimal expenditure on hardware. It is premature at this time to make estimates of the resources required to conduct a full-scale operation. Individual items in Table 1 of the BWID Test Plan Guidance $^{2}$ cannot be meaningfully addressed.

\subsection{Input, Output, and Test Conditions}

Input is the known configuration of materials in the Cold Test Pit. The output measured during the field tests will be the sensors' responses. Test conditions will be normal summer weather conditions at an open air site.

\subsection{Test Overview and Schedule}

The test trench for the performance tests will be $110 \mathrm{ft}$ long $\times 12 \mathrm{ft}$ wide as shown in Figure 4 . The complete survey of the test trench will require 10 separate trolley set-ups beginning near the Large Object Zone and progressing toward the Random Dump Drums Cell. It is anticipated that data collection at each trolley position will require 1 to 2 days. The complete set of tests should take 
Excavation: $110 \times 10$ feet, approximately 4 feet deep

Survey: 4 sensors $\times 10$ levels $\times 10$ sites $=400$ levels (209 collected in FY93)

Sensors: magnetic, EM38 $-\mathrm{H}$ and $-\mathrm{V}, \mathrm{EM} 61$, ground radar
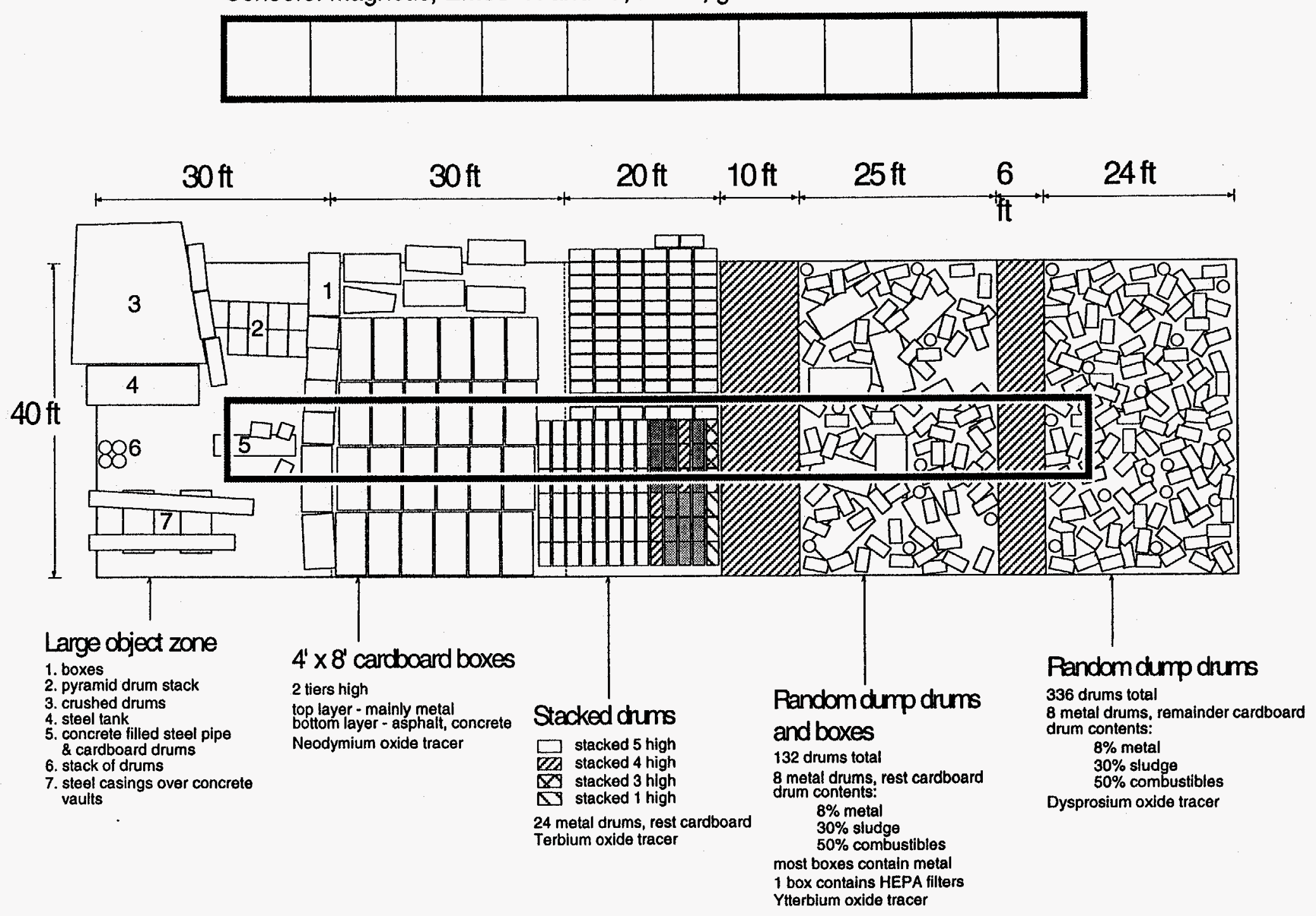

Figure 4. INEL's Cold Test Pit showing area of the proposed excavation for the digface characterization field tests. 
15 to 20 field days to complete. The work is scheduled to begin July 13 and should be complete August 12. The trolley will be disassembled at the completion of the tests, removed from the site, and the trench will be returned to its pretest condition.

\subsection{Test Methods}

Unique features of a digface characterization are (a) measurements can be easily made at fine grid intervals using the trolley structure, (b) measurements are made from multiple planes as the digface advances, and (c) measurements are made from close-up viewpoints just before the materials are exposed and retrieved. The performance tests are designed to capture these aspects of digface characterization.

Multisensor data will be collected over a long, narrow portion of the Cold Test Pit that includes several different types and geometries of waste. Data collection will begin 1 to $2 \mathrm{ft}$ above the surface of the Cold Test Pit and will be continued to a depth of 4 to $5 \mathrm{ft}$ below the ground surface. This will yield multiple planes of data, from multiple sensors, including measurements made within about $1 \mathrm{ft}$ from the top of the buried waste. These data will be representative of the data that can be collected during overburden removal of an actual hazardous site. The characterization data will be analyzed to estimate the waste conditions over the length of the trench. Following data collection, test holes will be hand dug if necessary to expose and document the actual configuration and condition of the buried simulated wastes for use in validating estimates made from the characterization data.

The primary uncertainty related to completion of the planned tests is the time required to make a full set of measurements at each trolley set-up position. Every effort has been made to expedite data collection so that the full length of the test trench can be surveyed over a 4-week period. The site has been pre-excavated, thus eliminating the need to schedule intermittent work for heavy excavation equipment. Laborers will conduct local hand excavations to expose buried objects allowing detailed measurements of their depth and position. This work can be performed after the trolley has been moved and will not delay the tests. The data acquisition equipment being used has been slightly modified to increase data collection rates compared with the FY-93 field tests. The modified equipment will be thoroughly checked before starting the field work, but malfunctions are always possible.

\subsection{Test Procedures}

The full procedure for collecting data over the test trench is described in Appendix A. In summary, the procedure begins with set-up and leveling of the trolley. Its ground position is surveyed and recorded in a Trolley Set-up Record. The first sensor to be deployed is then mounted on the trolley, and measurements are commenced beginning at the highest elevation to be surveyed. After completion of a full sequence of data collection profiles at the first level, the sensor is lowered to the next level and the operation repeated (see Figure 5). A Data Acquisition Record is filled out (and entered into the data base) for each level of data collection. The Data Acquisition Record contains information needed to calibrate the raw data and compute world coordinates for each data point. This sequence of events is repeated for each sensor and trolley location. 
Ground radar data will be collected manually along profiles run parallel to the trench long direction. The radar surveys will be conducted after completion of all trolley data collection. Start and end points of the radar profiles will be surveyed. Measuring tapes will be used to mark intermediate points at 5-ft intervals.

The overall conduct of operations will adhere to the general guidelines laid out for geophysical surveys in the Environmental and Earth Sciences Standard Operating Procedures Manual, Sections 2.14.1 and 2.14.3. ${ }^{3}$ A copy of these procedures will be maintained onsite.

\subsection{Diagrams of Test Procedure}

Figure 5 shows the sequence of activities required to make measurements at each trolley set-up location. Figure 4 shows the planned trolley locations required to survey the full test trench.

\subsection{Contingency Plans}

Tests will be discontinued in the event of weather conditions that compromise personnel safety, equipment, or test results. The BWID project manager will then evaluate the situation to determine the most appropriate method to meet the test objectives.

If the field tests are delayed by equipment malfunctions, nonavailability of key personnel, or general slow operations, a decision will be made as to the best means of completing or terminating the work. This decision will be made jointly between the principal investigator, lead engineer, and BWID project manager. Redundancy has been built into the test procedure so that the test objectives can be met adequately even if operations are terminated before completion of the entire survey. The Cold Test Pit will be available until at least August 24 if testing slips beyond the planned August 10 completion date. However, any delay beyond August 10 will likely impact completion of the draft final evaluation report.

\subsection{Performance Objectives}

The principal performance objective for the FY-94 field tests is to obtain adequate data to evaluate the capabilities of a digface characterization system for object detection during overburden removal. The specific desired capabilities are listed in Section 1.3. Data will be considered adequate if at least four levels of trolley data are collected over the entire test trench using at least two sensors and at least three ground radar profiles are collected over the entire trench length.

\subsection{Applicability of Testing to Customer Need}

Digface characterization fills a niche within site remediation that was essentially unrecognized prior to FY-92 when BWID began earnest development of the concept. The concept has since been loosely integrated into the overall BWID waste retrieval vision, but the specific role of the digface characterization system has not been fully defined. One reason for the current loose integration is lack of knowledge regarding the actual capabilities of a digface system. The FY-94 field tests discussed in this test plan will begin to assess actual capabilities of the system under realistic conditions. This is an obvious development step and will provide DOE with a clearer understanding 


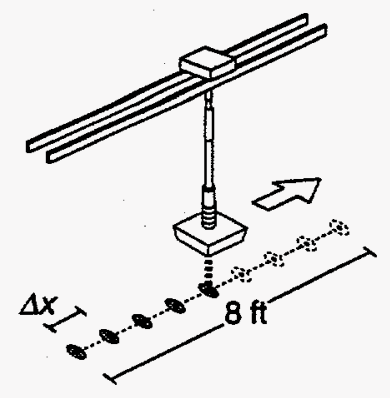

\section{Surveying a profile}

at 6 inch spacing - 17 data points

at 12 inch spacing - 9 data points

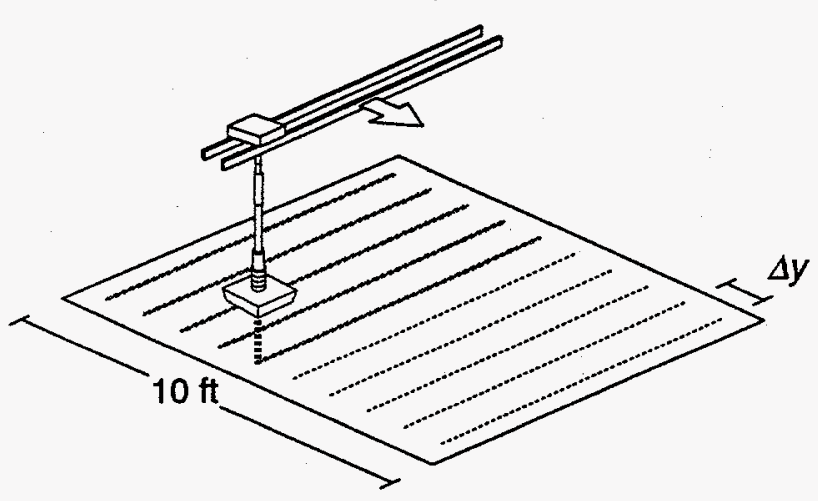

Surveying a level

at 6 inch spacing - 357 data points at 12 inch spacing - 99 data points

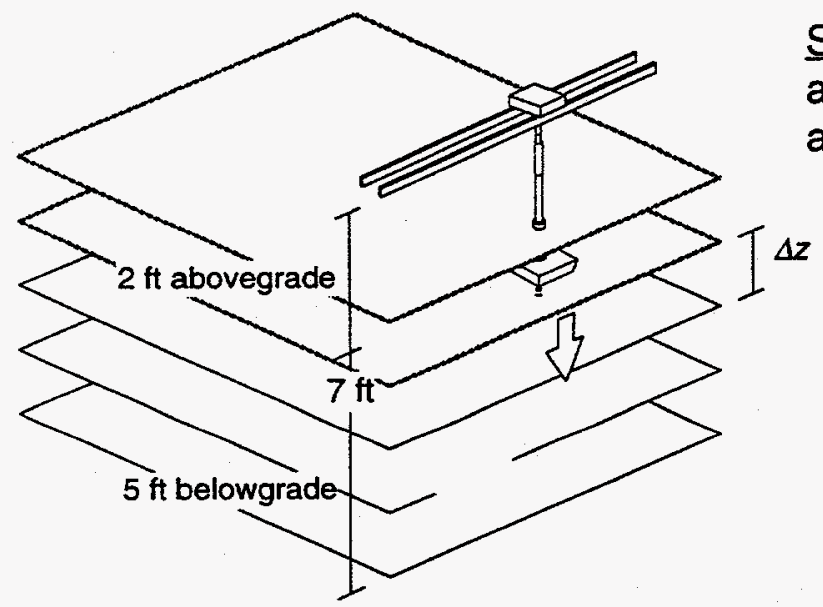

\section{Surveying a cell}

at 6 inch spacing - 6069 data points

at 12 inch spacing - 891 data points

Figure 5. Sequence of trolley motions required to survey a volume. 
of the potential importance of digface characterization for clean-up of hazardous sites within the DOE complex. 


\section{SEQUENCE OF ACTIVITIES}

The basic sequence of events for the FY-94 field experiments will be as follows:

1. Assemble and test the digface characterization system including trolley, PC-based data acquisition system, software, and sensors in Idaho Falls.

2. Prepare the Cold Test Pit test trench.

3. Transport equipment to site, reassemble, and retest.

4. Milestone: Site and equipment ready for field tests.

5. Perform complete data collection over test trench including surveys of each trolley location and ground radar profiles.

6. Milestone: Initial data collection complete.

7. Decision Point: Conduct preliminary data analysis to determine if additional testing is necessary.

8. If required, perform additional testing.

9. Disassemble test equipment and remove from site.

10. Hand excavate to expose buried objects and conduct surveys of their locations.

11. Restore Cold Test Pit to pretest condition.

12. Milestone: Field work complete.

13. Conduct detailed data analysis in Idaho Falls.

14. Write draft final report.

15. Milestone: FY-94 workscope complete. 


\section{SAMPLING AND DATA}

The following sections cover details of data collection.

\subsection{Applicability to CERCLA Criteria}

BWID has pursued development of the digface concept based on the belief that it will contribute to protection of human health and environment during cleanup of certain types of hazardous sites. Table 2 attempts to summarize the applicability of the digface characterization system to this purpose in the context of Comprehensive Environmental Response, Compensation, and Liability Act (CERCLA) criteria listed in the BWID Test Plan Guidance. ${ }^{2}$ The data being collected during the FY-94 digface characterization field tests are needed to understand the system's basic capabilities for detecting dangerous or unexpected conditions during excavation of a hazardous site.

\subsection{Data Collection Technique}

Data collection will be performed using a nonmetallic trolley, which is a precision mechanical device capable of scanning sensors across an area as large as $12 \times 10 \mathrm{ft}$ at depths up to $8 \mathrm{ft}$ below the transverse beam (see Figure 6). Sampling of sensor response is performed automatically at regular user specified intervals as the trolley is traversed in the $\mathrm{x}$ - direction. Movement of the trolley is manually enacted.

Sensors are connected by cable to an analog-to-digital converter located on the trolley. Digitized signals are communicated continuously to a PC-based data acquisition system. The data acquisition system also receives signals from distance measurement devices attached to the two main beams of the trolley. The data acquisition system monitors sensor position and samples the sensor output at the set spatial interval. The system is sufficiently precise to support data acquisition at sample intervals as small as $1 \mathrm{in}$.

The $\Delta x$ and $\Delta y$ data interval are normally set to be less than or equal to $1 / 2$ the depth to the shallowest expected targets. No guidelines have yet been established for setting the $\Delta \mathrm{z}$ interval. This interval is normally set at 0.5 to $1.0 \mathrm{ft}$. 
Table 2. Applicability of digface characterization to CERCLA criteria.

Criteria

Applicability

1 The digface characterization system will provide the earliest possible warning of hazardous conditions during site cleanup. The alternative is to detect these conditions after they have been released and dispersed into the local environment, which may be a containment structure or open air.

$2 \quad \mathrm{NA}$

3 Long-term effectiveness of site cleanup is not impacted by digface characterization.

4 Digface characterization can potentially identify hazards before they are disturbed. The alternative approach cannot, leading to the probability that employment of digface characterization can reduce the spread of contaminants and thus the volume requiring treatment

5 Short-term effectiveness of site cleanup is not impacted by digface characterization.

6 The alternative is easily implemented since it involves essentially a "no action" approach.

7 The alternative to digface characterization costs nothing since it is essentially a "no action" approach. However, the costs for (a) down time due to encountering sudden dangerous conditions and (b) additional treatment due to spreading of contamination by excavation equipment may be large. Digface characterization is aimed at avoiding these costs.

$8 \quad$ NA

$9 \quad$ NA 


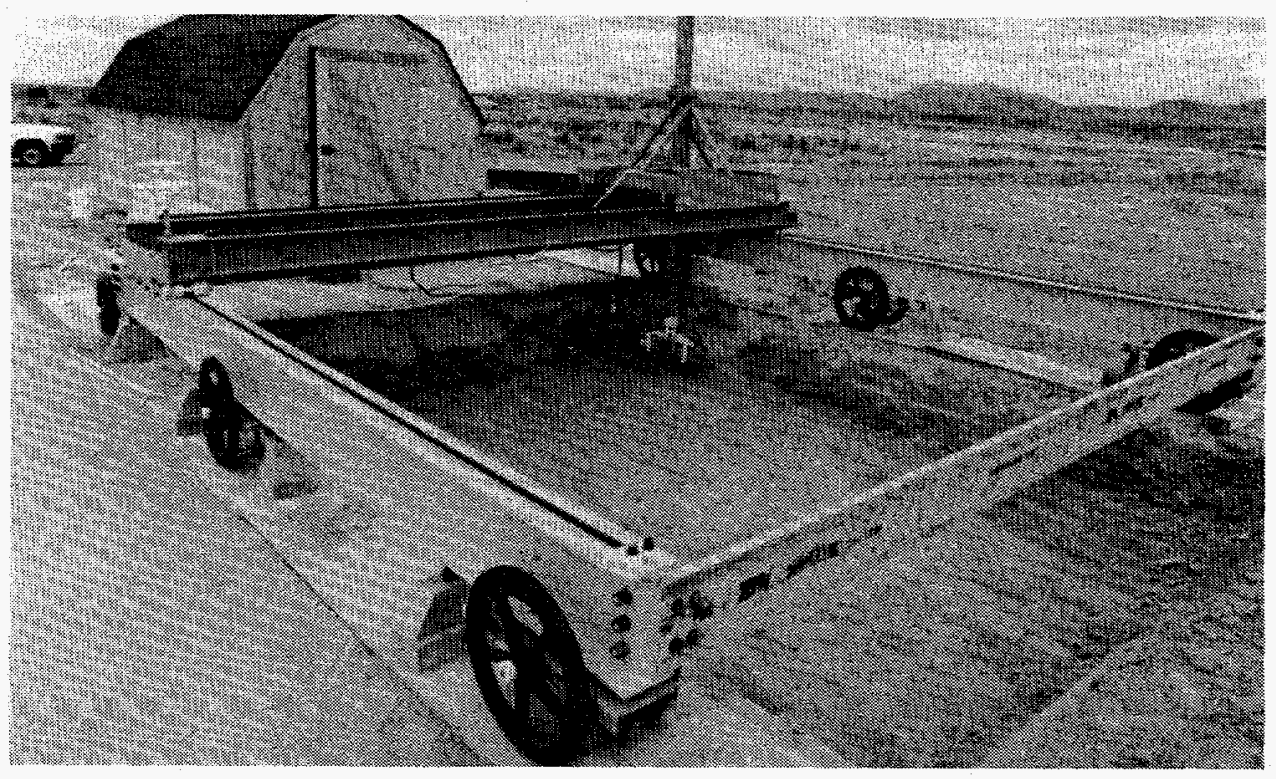

Figure 6. Manual trolley used for field experiments. 


\subsection{Sampling and Data Collection}

At the beginning of each field experiment, the trolley will be positioned over a test area and leveled. The position of the trolley with respect to a global coordinate system will be recorded in a Trolley Set-Up Record in the data base. Data will be initially collected on a 6-in. cubic grid. However, this plan may be modified for different areas based on initial measurements. The $\Delta x, \Delta y$, and $\Delta \mathrm{z}$ increments (as well as other acquisition information) will be recorded in Data Acquisition Records within the data base. The data base requires one Data Acquisition Record for each scan level.

The test area survey will proceed in a series of elevation increments beginning with the free space above the initial undisturbed ground. The trolley will be conveyed across the test area in a systematic manner so that a planar data set on a regular $\Delta x-\Delta y$ grid is collected. The trolley will then be lowered by $\Delta z$ in elevation and another planar data set collected. This sequence will continue until the trolley position approaches the excavated ground level.

\subsection{Sampling and Analysis Plan}

The FY-94 digface characterization field tests do not require a sampling and analysis plan. 


\section{DOCUMENT CONTROL}

The digface characterization performance tests will generate a large volume of data over a 4-week period of time. The data acquisition system has been specifically designed to automate much of the data collection and formatting. The data acquisition system acquires and converts raw sensor output (i.e., voltages) to digital values in appropriate units, places a position stamp on the data, and writes the result to permanent storage in the appropriate format for later data processing and image generation.

\subsection{Data}

The data will be incrementally archived onto floppy diskettes each day. These data will be transported and stored at the Research Office Building in Idaho Falls. Weekly data backups will be done in Idaho Falls on the post-processing computer using a $250 \mathrm{MB}$ QIC-80 tape unit. Once testing is complete, a copy of all data and logbooks will be delivered to BWID.

During data collection, Trolley Set-up Records will be filled out each time the trolley is relocated. Data Acquisition Records will be filled out for each level of data collected. These records will provide permanent, independent documentation of the data contained in the data base.

\subsection{Test Plan}

Major changes to this test plan can be made at any time subject to approval by the BWID project manager. A major change is defined as any modification of the data quality or test objectives as defined in Section 1.3. These changes will be in writing and attached to the front of the original test plan. A designated master copy containing the original test plan and all subsequent revisions will be located in the field with the test apparatus.

The principal investigator, or a designated alternate, may modify the test plan to account for unanticipated conditions that might occur during the experiments. These changes will be documented by striking out and adding the appropriate text to the master copy of the test plan or by making notes in the field notebook. All such changes to the test plan will be reported to the BWID project manager at the end of the day.

\subsection{Reporting and Logbooks}

Applied Geosciences has established a project file that contains a chronology of all official documentation (e.g., Interoffice Correspondence, purchase orders) associated with the Digface Characterization Project. A master field logbook will be kept by the principal investigator (or designated alternate) and conform to the practices described in the Environmental and Earth Sciences Standard Operating Procedures Manual, Sections 2.14 .1 and 2.14.3. ${ }^{3}$ Copies of these procedures will be kept onsite during the testing. Copies of all data and logbooks will be delivered to BWID for archiving. 


\section{ANALYTICAL METHODS}

Not applicable. 


\section{DATA REDUCTION, VALIDATION, AND VERIFICATION}

\subsection{Data Reduction}

Most data reduction for this effort will be done automatically by the computer-based data acquisition system. This involves conversion of raw sensor output (volts) to a digital value in the appropriate engineering units. Analog output ranges and conversion factors for the sensors to be used in the performance testing are listed in Table 3. Detailed information on these sensors has been compiled into Appendix B.

Table 3. Operating parameters and conversion factors for the trolley deployed digface characterization sensors.

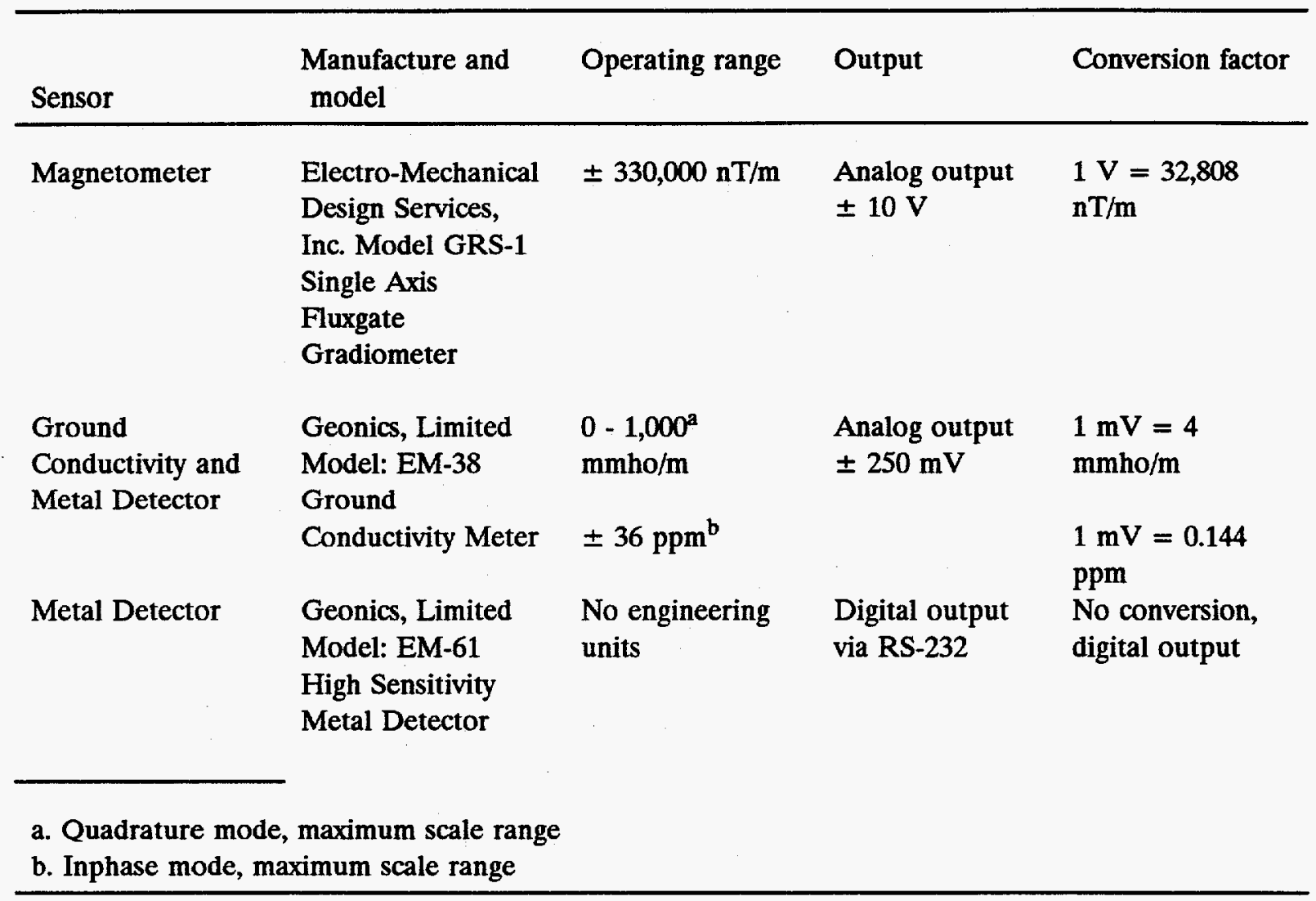




\subsection{Data Validation}

A visual inspection of the data will be performed to ensure that the data are reasonable as compared to previously encountered similar conditions. The data acquisition system will have on-line data display capabilities to facilitate data validation during the tests. The data acquisition system also provides direct warning when input analog voltage from any of the sensors equals or exceeds the manufacturer's recommended range for correct operation.

Validation of position data will be performed using distance scale marks etched onto the main structural beams of the manual trolley. Electronic position will be compared against the physical position of the trolley by reference to the etched scales. Position validation will be performed at least once following each change of the z-position of the trolley.

Data verification involves ensuring that the data are transcribed correctly during transfer from one media to another. Since the data will be handled entirely by electronic means, the data verification process is minimized. Copies of raw sensor output will be maintained permanently, providing a means to verify any or all portions of the data set at any time. Trolley position, date, and time of day will remain permanently stored with each unit of raw sensor output.

\subsection{Responsibility for Data Validation}

Visual inspection of incoming data will be done by the principal investigator or by an alternate designated by the principal investigator.

\subsection{Acceptance Criteria}

Data collected during the field tests will be accepted only if within the manufacturer recommended operating range for each sensor. Data falling outside this range will be flagged immediately by the data acquisition system or by field personnel. Flagged data will be removed from the data base following completion of the data collection increment if possible. Otherwise, these data will be removed during post-processing.

The acquired data will also be evaluated by the principal investigator for reasonableness, based on experience with other similar data collected in similar circumstances. Unacceptable data will be deleted and recollected. Poor data may indicate sensor damage or malfunction. If so, the indicated sensor will be repaired or replaced prior to repeating data collection.

These are standard acceptance criteria for geophysical investigations. 


\section{QUALITY ASSURANCE}

\subsection{General}

The FY-94 digface characterization field tests will be subject to Quality Level B requirements. The applicable Quality Program Plan is QPP-044, "ERA Department Quality Program Plan." Nonconformance poses no threat to human health or the environment. Any nonconformance issues will be the responsibility of the BWID project manager and principal investigator.

\subsection{Quality Control Methods}

Quality control can be maintained by establishing that the experimental hardware is in proper working order before testing and that sensors are responding properly during conduct of testing. Correct hardware functionality can be ensured by performing a visual inspection of the sensor delivery system and data acquisition system at the beginning and end of each day. This inspection will concentrate on abnormal wear on mechanical components and integrity of all electrical connections. Since the tests will occur in outdoor conditions, the general cleanliness of the equipment will be assessed and proper cleanup and preventative maintenance will be done as required. This may involve removing dust with compressed air equipment and lubrication of moving parts.

Should an equipment malfunction, or an abnormal operating condition occur, field operations will be suspended until the problem is resolved. If the problem is considered minor, field operation may continue at the discretion of the technical field leader(s).

Sensor data quality will be monitored through methods discussed in the next section.

\subsection{Specific Quality Control Procedures}

Sensor precision refers to the property of a sensor that causes it to always output the same response when at the same location and under the same conditions (i.e., no component of the response is time variable). Temperature fluctuations and electronic drift are common sources of sensor instability, which can cause poor repeatability. Of the three sensors listed in Table 3 , only the EM-38 requires periodic reset of the electronics to counteract electronic drift. The remaining sensors are either factory or laboratory calibrated. As a consequence, the EM-38 will be calibrated twice daily according to manufacturer's procedures at a designated calibration station. In addition, repeat surveys of small areas will be conducted at least twice daily with all sensors in regular use for that day and ambient temperature and humidity will be recorded at regular intervals. While these procedures do not arrest instrument drift, they provide a means to recognize its presence and severity.

In the present context, relative accuracy refers to the property of a sensor that causes it to respond properly as the sensor is moved about within the volume of influence surrounding materials to which that sensor is sensitive. This may be contrasted with absolute accuracy, which can only be established by testing the instrument over its full range through comparison with known standards. For the digface characterization tests, assessment of relative accuracy (or data validation) will rely primarily on the past experience of the operators. Absolute accuracy is listed in Table 3 based on manufacturer's quotations. 
The digface characterization performance testing will adopt a set of specific quality control procedures that will govern all data acquisition. The quality control procedures for digface characterization performance testing are stated as follows:

1. Data collected during performance testing will be within the manufacturer's recommended operating range for each sensor; data falling outside this range will be flagged immediately by the data acquisition system or by field personnel. Flagged data will be deleted from the data base.

2. The EM-38 will be calibrated at least twice daily at a designated calibration station when it is in regular use.

3. Repeatability of all sensors will be monitored by duplicating data acquisition along a selected data profile at least twice daily for all sensors in regular use for that day. Standard statistical methods will be applied to compute the precision of each sensor.

4. Proper function of the trolley positioning system will be monitored by comparing the electronic position against the physical position (through reference to scale marks) at least once following each change in the $\mathrm{z}$ position of the trolley.

\subsection{Change Documentation}

Changes in equipment, procedures, and documents can be authorized at any time by the principal investigator. These changes will be noted in the field notebook and signed. The BWID project manager will be apprised of any changes on a weekly basis.

\subsection{Audit Procedures}

The project manager will conduct a minimum of two internal surveillance visits to the test site during the course of the field tests.

BWID Quality and Safety will review the field activities on a weekly basis. 


\section{EQUIPMENT AND INSTRUMENTS}

\subsection{Equipment and Suppliers}

The equipment required for the digface characterization tests is provided from within the Digface Characterization Project. The major pieces include the overhead trolley sensor delivery system, PC-based data acquisition system, and sensor subsystems.

A $120 \mathrm{VAC}$ gas powered generator will be provided by BWID.

\subsection{Instrument Specifications}

Range, accuracy, and signal strength for each of the sensors is listed in Table 3.

All equipment is designed for outdoor use and can withstand normal temperature fluctuations, wind, and dust conditions. The data acquisition computer must be located within a watertight structure. This structure will be moved alongside the trolley as the testing proceeds.

\subsection{Calibration}

Only the EM-38 requires regular calibration. The EM-38 will be calibrated at a permanent calibration station located nearby the work area. A rigid stand will be used to support the instrument during the calibration procedure. The procedure is specified in the operating manual for the EM-38, which will be located at the test site at all times.

\subsection{Equipment Maintenance}

Little routine maintenance is required for the test equipment. The rollers and tracks on the trolley will be wiped clean before beginning operations each day. The EM-38 will be fitted with new batteries at the beginning of each week.

\subsection{Equipment Sensitivity to Environmental Conditions}

The trolley, data acquisition system, and sensors can withstand normal temperature ranges, wind, and dust conditions. Operations will be suspended during periods of rain since the electrical connections are not watertight. 


\section{SUPPLIES, UTILITIES, AND FACILITIES}

Implementation of this test plan hinges upon the availability and support of personnel at the Cold Test Pit. This includes labor and/or equipment to prepare the site and to excavate the test cells to simulate a retrieval operation, which will be supplied by the RWMC labor pool. Other site requirements include the availability of $120 \mathrm{Vac}$ power and a secure enclosure for housing the data acquisition equipment, which will be supplied by BWID. 


\section{HEALTH AND SAFETY}

No special health and safety issues apply to this test activity. The standard gatehouse and Hazards Communication training are required for all personnel on this project. The EG\&G Idaho Safety Manual will govern all activities at the Cold Test Pit. 


\section{RESIDUALS MANAGEMENT}

No hazardous wastes or residuals will be generated as a result of this activity. 


\section{REFERENCES}

1. R. A. Hyde and J. L. Morrison, Fiscal Year 1994 Buried Waste Integrated Demonstration Test Goals and Objectives, EGG-WTD-11112, EG\&G Idaho, Inc., 1994.

2. L. C. Rounds and J. K. McDonald, Buried Waste Integrated Demonstration Technology Test Plan Guidance, EGG-WTD-9800, Rev. 1, EG\&G Idaho, Inc., 1994.

3. EG\&G Applied Geosciences Unit, Environmental and Earth Sciences Standard Operating Procedures Manual, EG\&G Idaho, Inc., 1993. 
Appendix A

General Field Procedures for FY-94 Digface Tests

A-1 
A-2 


\section{Appendix A \\ General Field Procedures for FY-94 Digface Tests}

1. Assemble trolley over the designated test area on the Cold Test Pit. The trolley will be assembled according to the procedures outlined in the Engineering Design File for the trolley. These procedures specifically address a number of safety issues for the protection of personnel and equipment.

2. Assemble data acquisition system onto trolley. The data acquisition system will be placed on the trolley. This addresses the electrical aspects of the trolley and includes the radial encoder system for tracking trolley position and the analog-to-digital converters that provide digital values of sensor output.

3. Perform final trolley leveling. The final trolley leveling will be done with a digital level purchased specifically for this project last year. A level trolley is critical for data quality.

4. Determine trolley position with respect to global coordinate system. The trolley position will be determined with respect to the global coordinate system established at the Cold Test Pit. The coordinates of each corner of the trolley will be determined by the triangulation from known datums.

5. Calibrate sensors before installation onto the data acquisition system. Sensors requiring calibration will be calibrated according to manufacturer's procedures. As of this writing, the Geonics EM-38 is the only instrument that requires a calibration. All other instruments are factory calibrated.

6. Attach sensor to trolley system. The sensor will be attached to the trolley system using the appropriate sensor jig. Specialized attachment jigs have been designed and constructed for each sensor. Output from the sensor will be monitored to verify proper sensor operation.

7. Survey test area. The test area will be surveyed with each sensor. The survey will normally consist of multilevel data. The data will be collected in sequence from the uppermost trolley mast elevation to the lowest elevation. Each elevation will consist of $x, y$, and field value(s) data. Typical data spacing will be $0.25 \mathrm{ft}$ in the $\mathrm{x}$-direction and $0.5 \mathrm{ft}$ in the $y$-direction. Typical elevation increments will be $0.5 \mathrm{ft}$.

8. Examine test data for validity. Each data set will be visually examined for sensor response and appropriate data validity. Data will be examined with text editors and/or by color contouring. Acceptance will be determined by the field leader and will rely on his/her experience and judgement.

9. Data archives. Data will be archived daily onto floppy disk and transported to Idaho Falls for further validity checks, data processing, and data presentation.

10. Transport trolley to next test area. After all data are collected for a given area, the trolley will be moved to the next test area and the sequence of activities will be repeated. 
Appendix B

Sensor Technical Specifications

B-1 


$$
\text { B-2 }
$$


EMDS GRS-1 Gradiometer

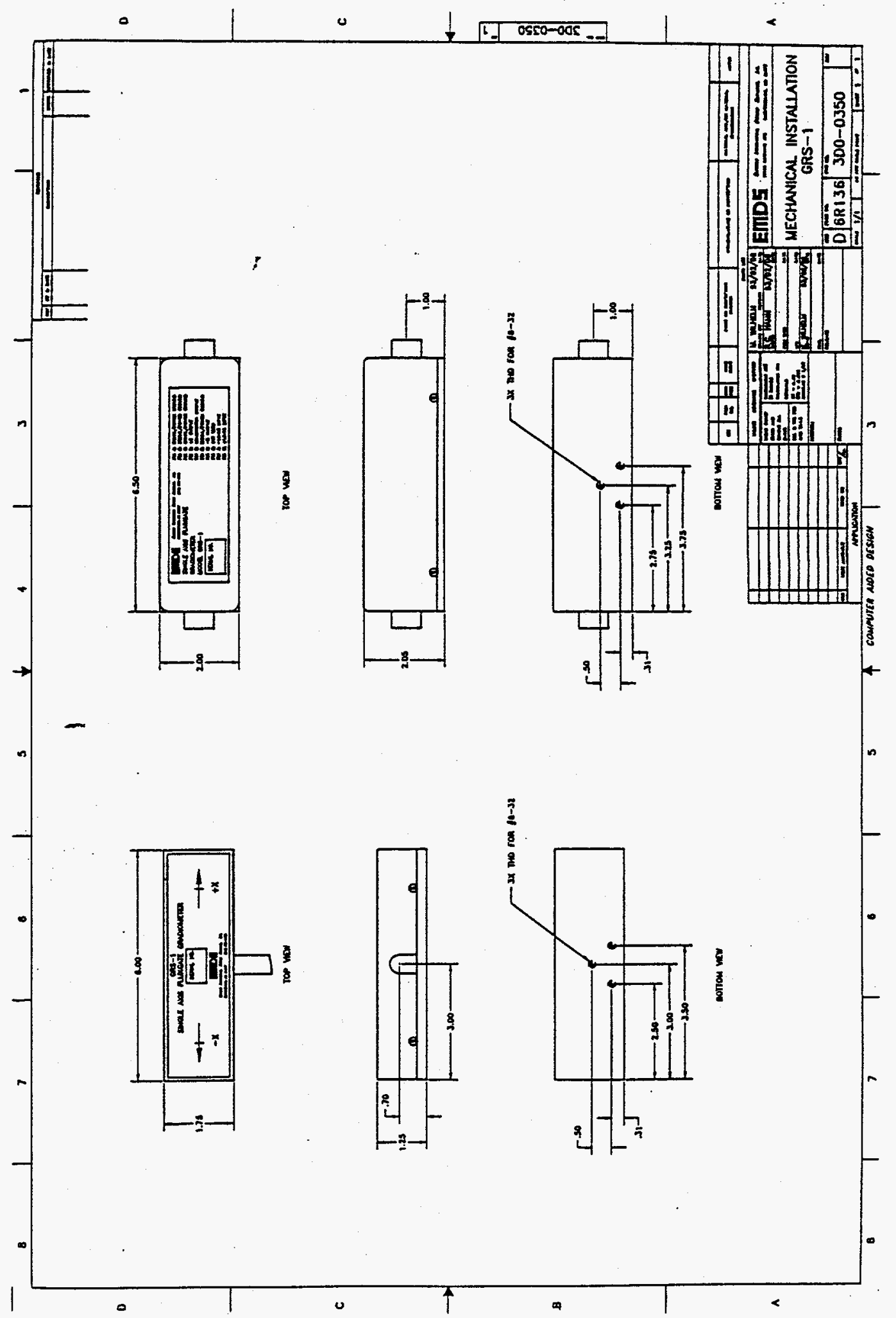


EMDS GRS-1 Gradiometer

\section{J. Instrument Specifications:}

$\begin{array}{ll}\text { Alignment Error: } & \leq 0.05 \text { degree } \\ \text { Susceptibility to } & \leq \pm 5 \mathrm{nT} / \pm 5 \text { Gauss } \\ \text { Perming: } & \pm 15 \mathrm{VDC} \\ \text { Input Voltage: } & \pm 40 \mathrm{milliamps}(+15 \mathrm{VDC}) \\ \text { Input Current: } & \leq 15 \mathrm{milliamps}(-15 \mathrm{VDC})\end{array}$

Magnetometer Range: $\pm 2,000$ milligauss $(200,000 \mathrm{nT})$

Gradiometer Range: $\pm 333 \mathrm{milligauss}(33,330 \mathrm{nT})$

Accuracy: $\quad \leq \pm 0.1 \%$ of Full scale

Linearity: $\quad \leq \pm 0.02 \%$ of Full scale

Magnetometer

Sensitivity:

\pm 5.00 Volts/Gauss

Gradiometer

Sensitivity:

\pm 30.0 Volts/Gauss

Scale Factor

Temperature Shift: $\leq 50 \mathrm{PPM} /{ }^{\circ} \mathrm{C}$

Noise: $\quad \leq 35$ picotesla $\mathrm{RMS} / \sqrt{\mathrm{Hz}}$ at $1 \mathrm{~Hz}$

$\leq 15$ picotesla RMS $/ \sqrt{\mathrm{Hz}}$ at $\mathrm{I} \mathrm{Hz}$

Output Ripple: $\quad \leq 5$ millivolt peak to peak a 2nd Harmonic

Analog output a

zero Field:

$\leq \pm 3.0$ millivolt

Zero shift with

Temperature:

$\leq 0.15$ nanotesla/ ${ }^{\circ} \mathrm{C}$

Output Impedance: $100 \mathrm{Ohm} \pm 5 \%$

Frequency Response: $-3 \mathrm{DB}$ a $>100 \mathrm{~Hz}$

Weight: $\quad \leq .82 \mathrm{Kg}$ (both sensors)

Cable Length: Electronic Case $16.5 \mathrm{~cm} \times 5.1 \mathrm{~cm} \times 5.3 \mathrm{~cm}$ Sensor Case $15.25 \mathrm{~cm} \times 3.15 \mathrm{~cm} \times 4.4 \mathrm{~cm}$ 


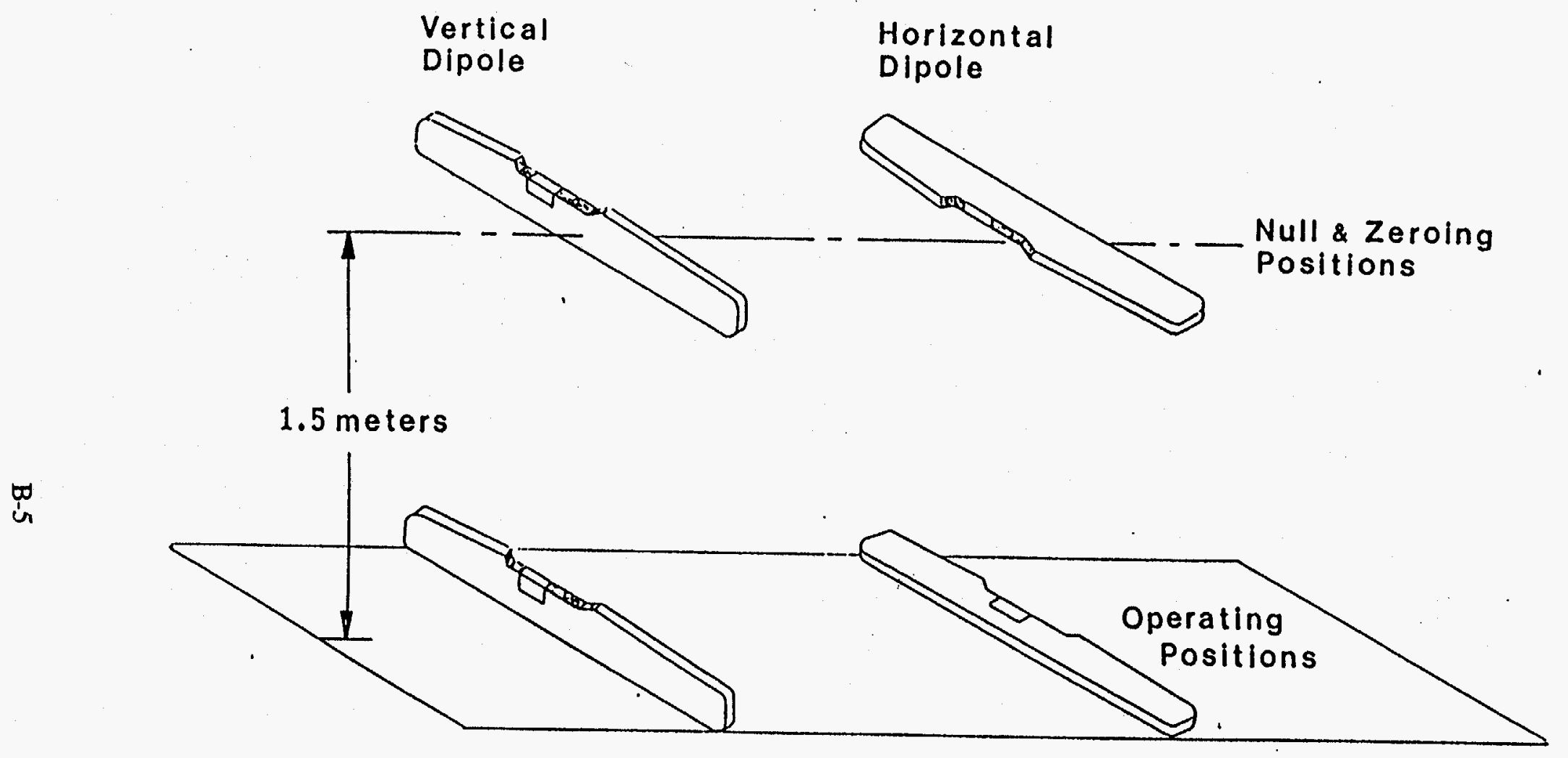

员

Fig.1 Vertical and Horizontal Dipole Positions 


\section{Geonics EM38}

\section{EM38 INSTRUMENT SPECIEICATIONS}

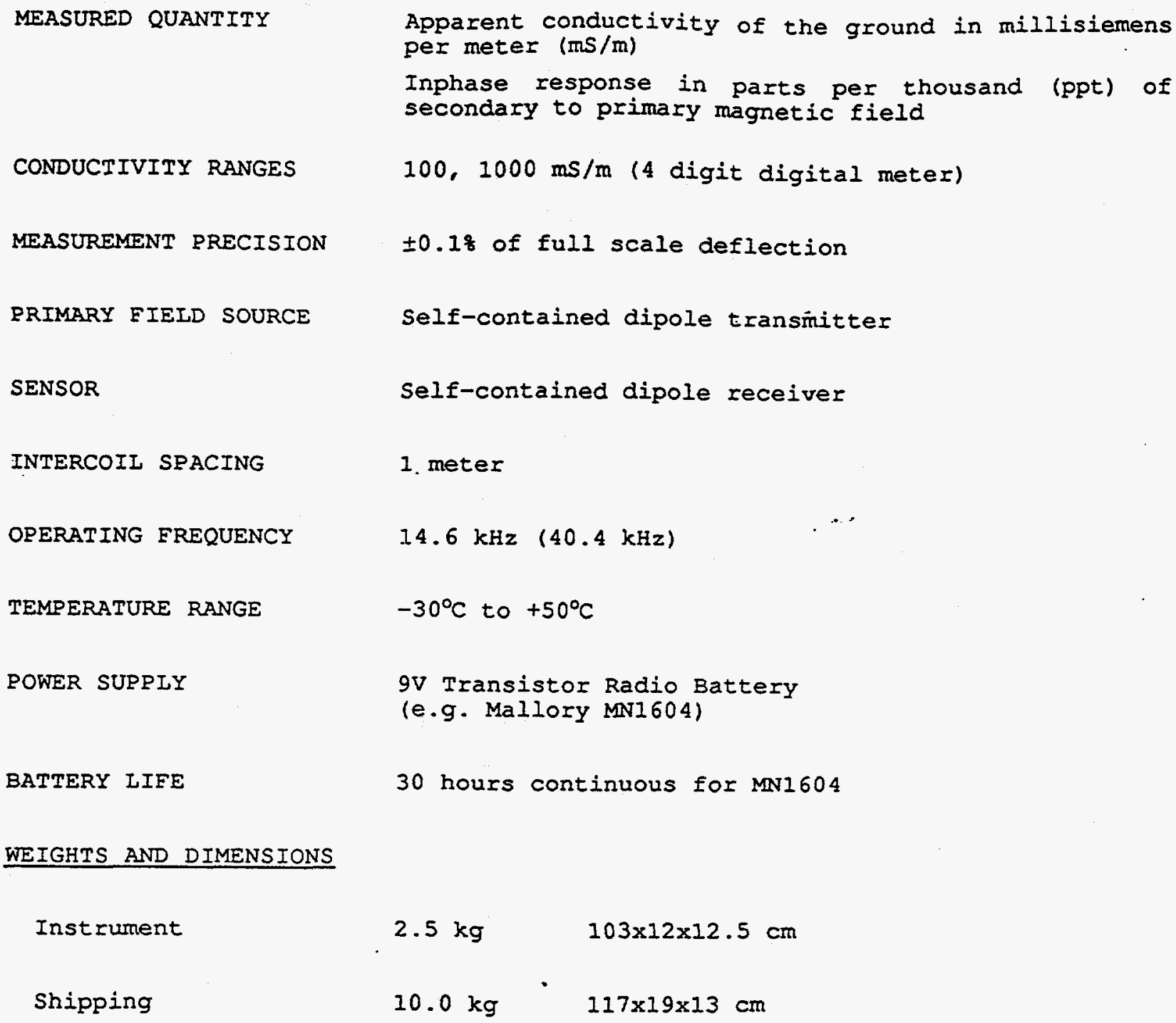


Geonics EM61

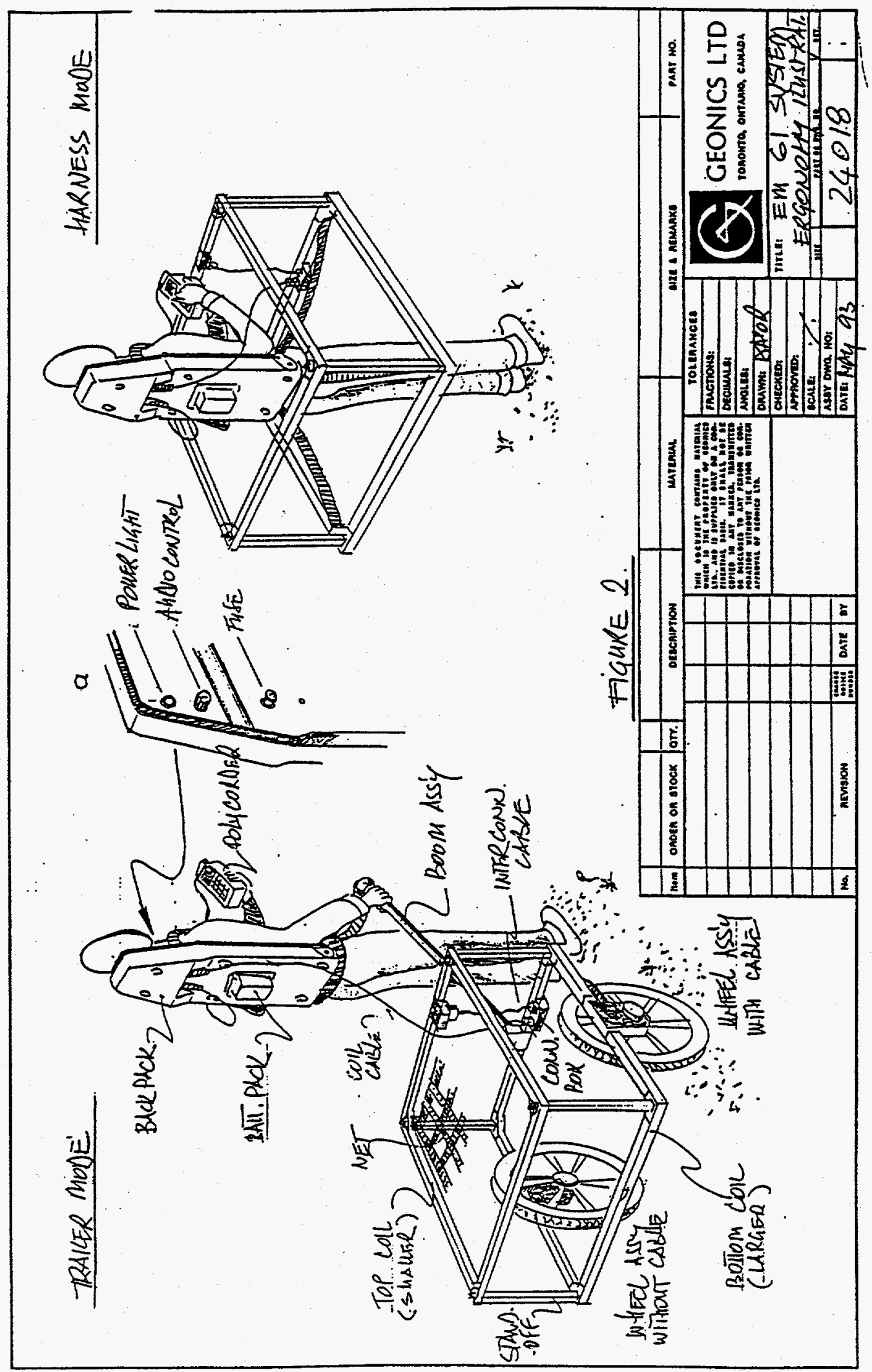




\section{Geonics EM61}

Technical Specifications

Measured Quantity : $\quad$ Two channels of secondary response in $\mathrm{mV}$

EM Source $\quad: \quad$ Air-cored coil, $1 \times 1 \mathrm{~m}$ size

Current Waveform : . Bipolar rectangular current with $50 \%$ duty cycle

EM Sensors : a) Main: Air-cored coil, $1 \times 1 \mathrm{~m}$ in size, coincident with EM source

: b) Focussing:Air-cored coil, $1 \times 1 \mathrm{~m}$ in size $40 \mathrm{~cm}$ above main coil

Maximum Output $\quad$ : $\quad 40000 \mathrm{mV}$ for low gain

$10000 \mathrm{mV}$ for high gain

Dynamic Range : 18 bits

Display : $\quad$ 4-line LCD with 16 characters per line

Data Storage : : Solid-state memory for up to 20364 records

Power Supply $\quad: \quad 12 \mathrm{~V}$ rechargeable battery for $4 \mathrm{~h}$ continuous operation

Operating Weight Backpack: $10 \mathrm{~kg}$; Coil Assembly: $16.5 \mathrm{~kg}$ (24 kg trailer mode)

\& Dimensions : Backpack: $60 \times 30 \times 10 \mathrm{~cm}$

Coil: a) Main: $100 \times 100 \times 5 \mathrm{~cm}$

b) Focussing: $100 \times 100 \times 2 \mathrm{~cm}$

Shipping Weight

$61 \mathrm{~kg}$ (86 kg with trailer)

\& Dimensions : $\quad 104 \times 104 \times 22 \mathrm{~cm}$ (Box 1)

$54 \times 54 \times 52 \mathrm{~cm}$ (Box 2) with trailer option only 
GSSI SIR-10 Radar

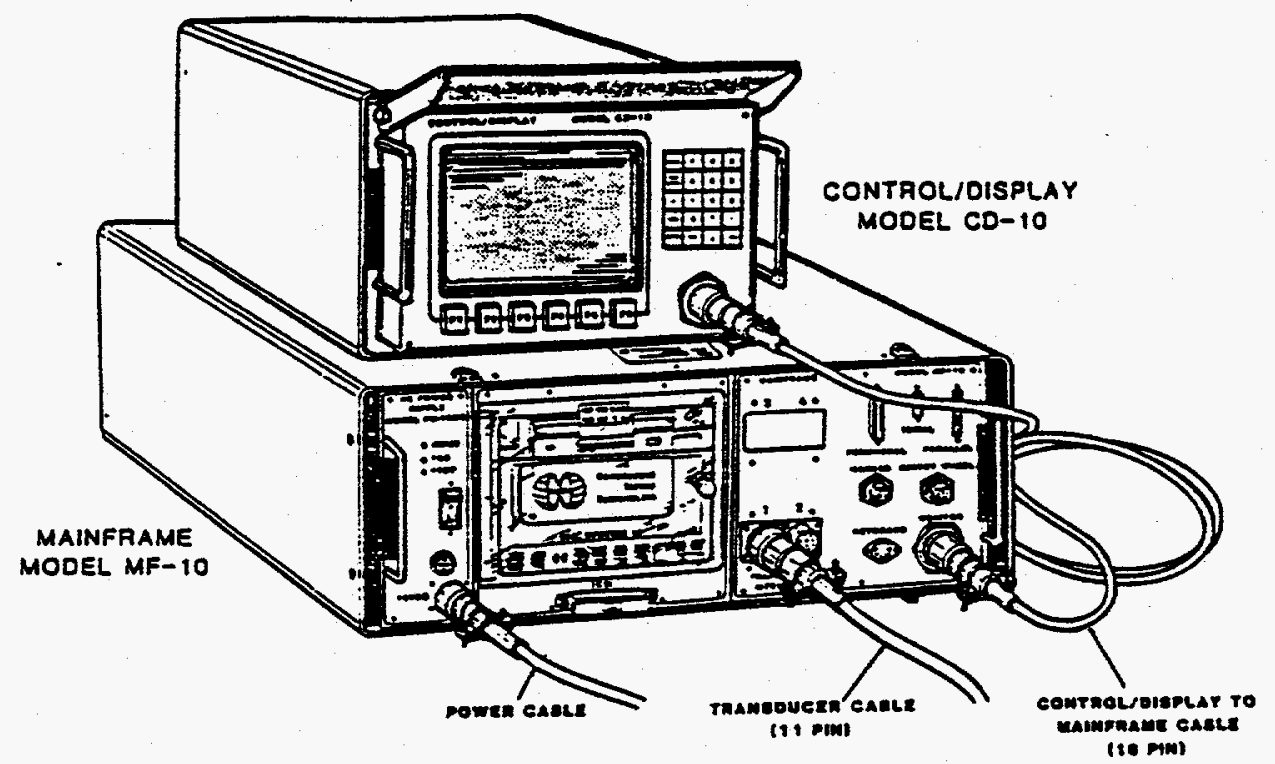

Schematic drawing of SIR System-10 components 
GSSI SIR-10 Radar

\section{Electrical Specifications}

INPUT POWER:

12 volts DC nominal with operating range of $11-15$ volts, 280 watts maximum

or

$115 / 230$ volts $A C$, with operating range of $100-120$

volts $\mathrm{AC}$ or $200-240$ volts $\mathrm{AC} 50 / 60 \mathrm{~Hz}, 280$ watts

RESOLUTION : 50 picoseconds between adjacent time locations along a reflection waveform

RANGE: 4-10,000 nanoseconds full scale, selectable

TRANSMIT PULSE REPETITION RATE: 2 to $78 \mathrm{KHz}$, selectable

ANALOG Quantization: 8 or 16 bits, selectable

ANALOG TO DIGITAL SAMPLING: $128,256,512$ or 1024 samples/scan, selectable

CLOCK SYNCHRONIZATION: internal crystal

CLOCK AND CALENDAR: Battery backup

SCAN RATE: 0.2 to 128 scans/second, selectable

TRANSDUCER COMPATIBILITY: All GSSI models and OYO models with the GSSI 505 model interface

\section{Mechanical Specifications}

Model CD-10 - including a cover with a carrying handle dimensions: $30.5 \mathrm{~cm} \times 29.2 \mathrm{~cm} \times 21.6 \mathrm{~cm}$ weight: $10.5 \mathrm{Kg}$

Model MF-10 - including a cover with a carrying handle dimensions: $44.1 \mathrm{~cm} \times 38.1 \mathrm{~cm} \times 17.8 \mathrm{~cm}$ weight: $18.0 \mathrm{Kg}$

Thermal Specifications

OPERATING TEMPERATURE: $-10^{\circ}$ to $+40^{\circ} \mathrm{C}$ external

RELATIVE HUMIDITY: < 90\% non-condensing 
GSSI SIR-10 Radar

\section{Hardware Specifications}

COMPUTER BOARD: 286 with 80287 math co-processor (386 Optional).

RADAR PROCESSOR: Motorola DSP56001, $20 \mathrm{MHz}$

ARRAY PROCESSOR: Sky 321-PC+ Array Processor Card

RAM MEMORY: 4 MB (Optional 8,12, and $20 \mathrm{MB}$ )

MASS STORAGE: 2.3 gigabyte Exabyte 8mm cartridge tape drive

- 15 meter tape stores 256 MBytes

- 54 meter tape stores 1024 MBytes

- 112 meter tape stores 2.3 GBytes

FLOPPY DISK DRIVE: 3.5 inch $(8.9 \mathrm{~cm}), 1.44 \mathrm{MB}$

EXTERNAL INTERFACE: Standard SCSI connector for external hard disk

DISPLAY: $19 \mathrm{~cm}$ EGA color monitor, 640 by 350 pixels, $21.8 \mathrm{KHz}$ non-interlaced

Connector Definitions, MF-10 Mainframe

For Connector Pin identification see Appendix F

TRANSDUCER INPUT CONNECTORS: Two female 11 pin connectors, four optional (BT02A-18-11S)

MONITOR: connection for MF-10 to CD-10, 3 meter cable (BT07A14-18S)

PARALLEL PORT: Standard Centronics Printer (DB25P)

PERIPHERAL PORT: Analog Signal, SOS and Control (DB25S)

SERIAL PORT: RS-232 (DB9P)

KEYBOARD CONNECTOR: Standard PC/AT compatible keyboard (5 pin DIN)

MARKER: 2 pin connection for GSSI Model 10 Remote Marker (BT07A8-2S)

SURVEY WHEEL: 4 pin connection for GSSI Survey Wheel Encoder (BT07A8-4S)

SCSI: $(3565-2000)$ 
GSSI SIR-10 Radar

POWER: DC 5 Pin (MS3122E14-5P)

AC 3 Pin $(6100-33)$

Connector Specifications, CD-10 Monitor

CD-10 to MF-10 Cable Connection (BT07A14-18P)

\section{Software Specifications}

CONTROL: Interactive menus via six soft keys, a numeric keypad, cursor keys, and five dedicated function keys.

CHANNELS: Can be selected to record 1, 2 , or 4 data channels.

DATA DISPLAY MODES: Linescan or Wiggle. Sixteen color bins to represent the amplitude and polarity of the signal when in linescan display.

RANGE GAIN: Manual adjustment from -26 to $+120 \mathrm{~dB}$. Gain curve resolution can be from one to eight segments over time range. Number of segments is user selectable. Option to apply automatic gain to equalize the power over the entire scan.

VERTICAL FILTERS: Filter the scans in the time domain. Low and high pass, Infinite Impulse Response (IIR), Finite Impulse Response (FIR) and Triangle filter types are available.

HORIZONTAL FILTERS: Filter the scans in the spacial domain. Stacking and background removal, IIR, Boxcar and Triangle filter types are available. Static stacking is also available. 